Prepared for the U.S. Department of Energy

under Contract DE-AC05-76RL01830

\title{
Analysis of the Russian Market for Building Energy Efficiency
}

T Lychuk

M Halverson

M Evans

V Roshchanka

December 2012

Pacific Northwest

NATIONAL LABORATORY

Proudly Operated by Battelle Since 1965 



\title{
DISCLAIMER
}

This report was prepared as an account of work sponsored by an agency of the United States Government. Neither the United States Government nor any agency thereof, nor Battelle Memorial Institute, nor any of their employees, makes any warranty, express or implied, or assumes any legal liability or responsibility for the accuracy, completeness, or usefulness of any information, apparatus, product, or process disclosed, or represents that its use would not infringe privately owned rights. Reference herein to any specific commercial product, process, or service by trade name, trademark, manufacturer, or otherwise does not necessarily constitute or imply its endorsement, recommendation, or favoring by the United States Government or any agency thereof, or Battelle Memorial Institute. The views and opinions of authors expressed herein do not necessarily state or reflect those of the United States Government or any agency thereof.

\author{
PACIFIC NORTHWEST NATIONAL LABORATORY \\ operated by \\ BATTELLE \\ for the \\ UNITED STATES DEPARTMENT OF ENERGY \\ under Contract DE-AC05-76RL01830
}

Printed in the United States of America

Available to DOE and DOE contractors from the

Office of Scientific and Technical Information,

P.O. Box 62, Oak Ridge, TN 37831-0062;

ph: (865) 576-8401

fax: $(865) 576-5728$

email: reports@adonis.osti.gov

Available to the public from the National Technical Information Service

5301 Shawnee Rd., Alexandria, VA 22312 ph: (800) 553-NTIS (6847)

email: orders@ntis.gov $<$ http://www.ntis.gov/about/form.aspx >

Online ordering: http://www.ntis.gov

This document was printed on recycled paper. 


\section{Analysis of the Russian Market for Building Energy Efficiency}

T Lychuk

M Evans

M Halverson

V Roshchanka

December 2012

Prepared for

the U.S. Department of Energy

under Contract DE-AC05-76RL01830

Pacific Northwest National Laboratory

Richland, Washington 99352 



\section{Executive Summary}

Three comparisons demonstrate the extent of the potential for energy efficiency in Russia. First, Russia is the world's third largest energy consuming country. Second, it consumes more energy per unit of Gross Domestic Product (GDP) compared to any of the 10 largest energy consuming countries. Third, in 2005 Russia ranked 12th out of 121 countries in terms of energy use per unit of GDP, or energy intensity. Although Russia has become more energy efficient compared to 1990, the country has not made as much progress as most other former Soviet Republics. Vast domestic energy supply, cold climate and inefficient technologies have ensured that high energy intensity remains endemic to every sector of the economy.

Not surprisingly, in 2008 energy efficiency was identified as a top priority for modernizing the Russian economy by then-president Dmitry Medvedev, who also affirmed that energy efficiency and conservation are among the five strategic priorities for modernizing Russia in general. Medvedev's 2008 decree set a target of 2020 to reduce Russia's energy consumption by at least 40 percent per unit of GDP compared with 2007 levels. This vision was followed by the federal law on energy saving, Federal Law No. 261-FZ, adopted in November 2009. A year later, the Russian Government approved a state program labeled "Energy Saving and Energy Efficiency Improvement to 2020."

The Russian energy efficiency market presents lucrative opportunities for U.S. environmental technology companies to improve energy efficiency, including the building sector of the country. This assertion was supported by the vice-president of Nalco Ecolab, David Johnson, who accompanied a U.S. trade delegation to Russia in June 2012.

This report provides analysis of the Russian energy efficiency market for the building sector from the perspective of U.S. businesses interested in exporting relevant technologies, products and experience to Russia. Chapter 1 provides data on energy consumption trends and opportunities for energy efficiency in the Russian residential building sector. It also briefly summarizes new energy efficiency legislation the country adopted in recent years. Chapter 2 provides data on construction trends in Russia, as well as describing current projects on building energy efficiency countrywide and in Moscow, St. Petersburg and Chelyabinsk specifically. It also outlines financial mechanisms used to finance most of the building energy efficiency projects in Russia today. Additionally, the chapter provides analysis of the types of energy efficient technologies and materials used in Russian buildings and supplies data about major producers and their share of the market. Lastly, the chapter describes export and technology transfer opportunities for interested U.S. companies to enter the building energy efficiency sector in Russia. Chapter 3 provides analysis of barriers for doing business on Russian building market for U.S. businesses. Chapter 4 lists some of the existing programs offered by the U.S. trade promotion agencies for interested U.S. businesses willing to enter Russian market for building energy efficiency.

This report aims to help U.S. energy efficiency and environmental technologies businesses to better understand the Russian building market to plan their market strategy. 


\section{Acronyms and Abbreviations}

ABOK

AHU

ASE

ASHRAE

BREEAM

CABA

CENEf

CHP

DGNB

EBRD

ECE

EIB

EPC

ESCO

EUR

Gcal

GDP

GEF

IEA

IFC

IFI

HVAC

$\mathrm{kWh}$

LEED

LED

$\operatorname{lm}$

lx

MSME
Non-commercial Partnership “ABOK” (Inzhinery po otopleniyu, ventilyatsii, konditsionirovaniyu vozdukha, teplosnabzheniyu i stroitelnoy teplofizike) [Russian Association of Engineers for Heating, Ventilation, Air-Conditioning, Heat Supply and Building Thermal Physics]

air handling units

Alliance to Save Energy

American Society of Heating, Refrigerating and Air-Conditioning Engineers

Building Research Establishment Environmental Assessment Method

Continental Automated Building Association

Center for Energy Efficiency

combined heat and power

Deutsche Gesellschaft für Nachhaltiges Bauen e.V. [German Sustainable Building Council]

European Bank for Reconstruction and Development

Economic Commission for Europe

European Investment Bank

energy performance contracting

energy service company

Euro

gigacalories

gross domestic product

Global Environmental Facility

International Energy Agency

International Finance Corporation

international financial institution

heating, ventilating and air conditioning

kilowatt hour

Leadership in Energy and Environmental Design

light-emitting diode

lumen

lux

micro, small, and medium enterprises 
Mtoe

MW

NEFCO

OECD

OPIC

PNNL

RSABC

RUB

RuGBC

UKTI

UN

UNDP

UNEP

UNFCCC

USD

USSR

W

WWF million tonnes of oil equivalent

megawatts

Nordic Environment Finance Corporation

Organisation for Economic Co-operation and Development

Overseas Private Investment Corporation

Pacific Northwest National Laboratory

the Russian Sustainable Architecture and Building Council

Russian ruble

Russian Green Building Council

U.K. Trade and Investment

United Nations

United Nations Development Programme

United Nations Environment Programme

United Nations Framework Convention on Climate Change

U.S. dollar

Union of Soviet Socialist Republics

watt

World Wildlife Fund 


\section{Contents}

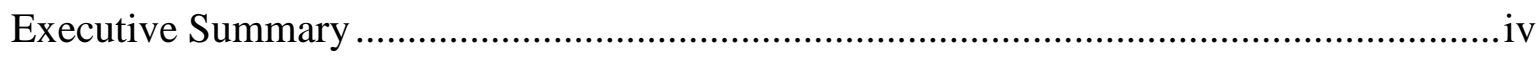

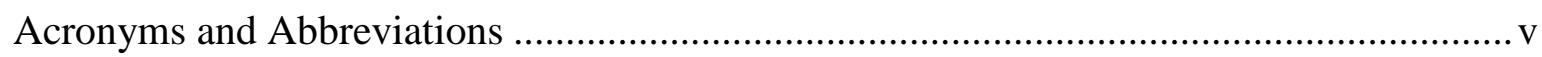

1. Energy Consumption Trends and Opportunities for Energy Efficiency ......................... 1

1.1 Russia's New Legal Framework for Energy Efficiency …………................................. 1

1.2 Energy Consumption Trends and Opportunities for Energy Efficiency in the Russian Residential Buildings Sector ................................................................................

1.3 Energy Consumption Trends and Opportunities for Energy Efficiency in the Russian Public and Commercial Buildings Sector ....................................................................

2. Energy Consumption Trends and Opportunities for Energy Efficiency .........................5

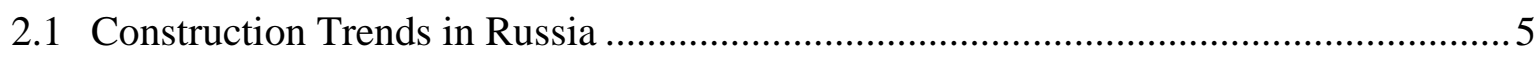

2.1.1 Information on Building Energy Efficiency Projects in Russia ............................ 8

2.1.1.1 Building Energy Efficiency Projects in Moscow ............................................... 13

2.1.1.2 Building Energy Efficiency Projects in St. Petersburg......................................... 14

2.1.1.3 Energy Efficiency Projects in Chelyabinsk ........................................................ 14

2.1.2 Mechanisms for Financing Energy Efficiency Projects in the Russian Building

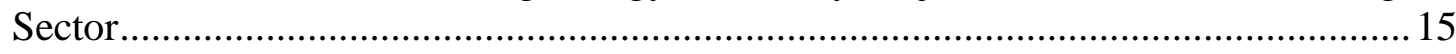

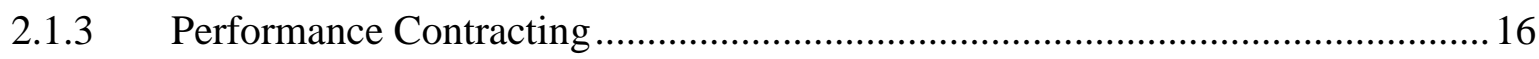

2.2 Types of Energy Efficient Technologies and Materials Used in the Russian Building

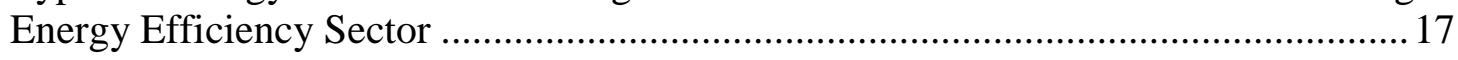

2.2.1 Heating Ventilation and Air Conditioning (HVAC) and Controls........................ 17

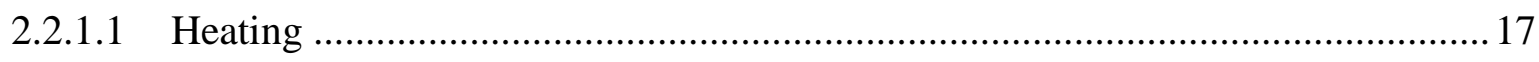

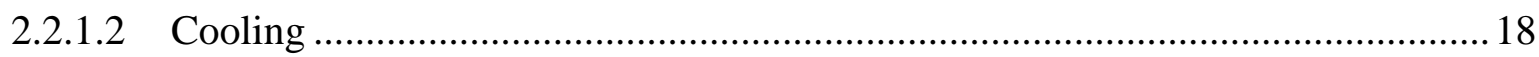

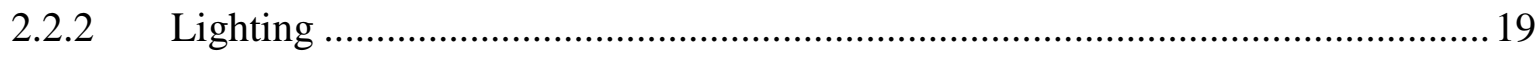

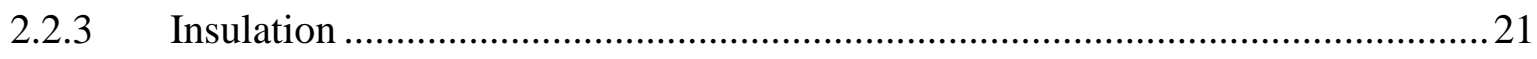

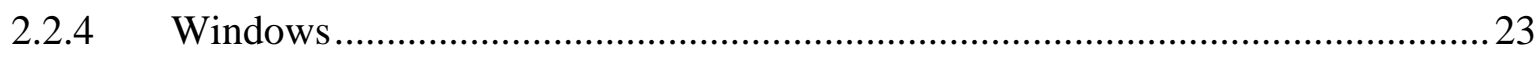

2.3 Export and Technology Transfer Opportunities for the Building Sector in Russia .....24

3. Analysis of the Barriers to Doing Business and Improving Energy Efficiency in

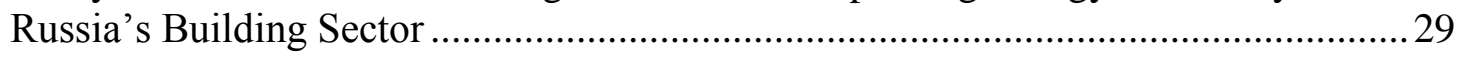

3.1 Barriers to Doing Business in Russia's Energy Efficiency Market .............................29

4. Programs of Support Offered by the U.S. Trade Promotion Agencies ..........................30

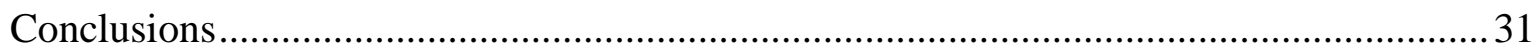

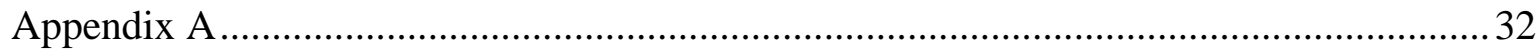

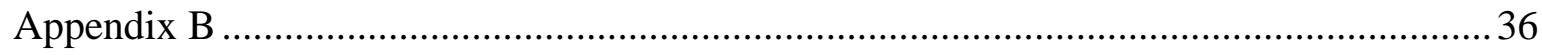

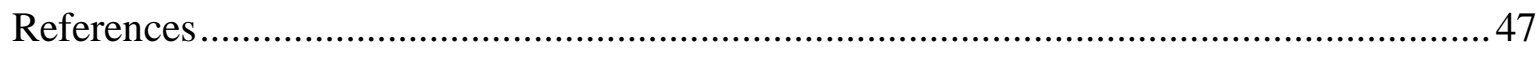




\section{Figures}

Figure 1.1 Residential Energy Consumption in Russia .................................................2

Figure 2.1 Lighting Technologies Used in Russia....................................................2 20

Figure 2.2 Breakdown of the Russian Thermal Insulation Market in 2009..................... 22

Figure 2.3 Major Insulation Producers in Russia in 2009........................................... 22

Figure 2.4 Russian Market Segmentation for Windows in 2009 .....................................23

\section{Tables}

Table 2.1 New Construction in Russia, 2005-2011 .......................................................5

Table 2.2 Residential Space Completed (Number of Apartments and Their Total Floor

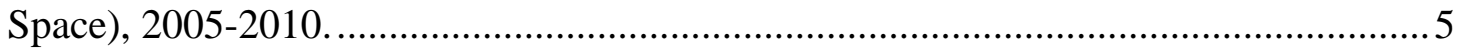

Table 2.3 Construction and Assembly Output (Value and Year-on-Year (Y-O-Y)

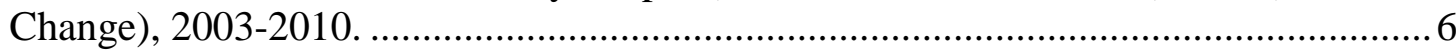

Table 2.4 Data on Unfinished Construction of Residential Buildings in Russia, 19952010 (Million $\mathrm{m}^{2}$ )

Table 2.5 Data on Construction of Social and Cultural Buildings in Russia ..................... 7

Table 2.6 Data on Construction of Buildings Used for Higher and Vocational Education (Thousand $\mathrm{m} 2$ ).....

Table 2.7 Additional International Energy Efficiency Projects in Russian Buildings ........ 10

Table 2.8 Energy Consumption for Russian Lighting Sector and Technical Potential for

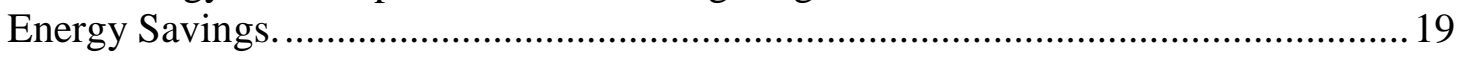

Table 2.9 Housing Market in Russia, 2010-2013 (USD Thousands).............................24

Table 2.10 Key Opportunities in the Russian Energy Efficiency Market........................25 


\section{Energy Consumption Trends and Opportunities for Energy Efficiency}

\subsection{Russia's New Legal Framework for Energy Efficiency}

In 2008, Russian President Medvedev launched a series of major policy reforms to promote broad improvements in energy efficiency in Russia. Medvedev's decree set a target of 2020 to reduce Russia's energy intensity, or energy consumption per unit of Gross Domestic Product (GDP), by at least 40 percent compared with 2007 levels. The 2008 decree was followed by the 2009 Federal Law No. 261-FZ “On Energy Conservation and Increasing Energy Efficiency” and the Government Program "Energy Savings and Energy Efficiency up to 2020", adopted by the Russian Duma in 2010. The program concedes that Russia's energy intensity is 2.5 times higher than the world's average and up to 3.5 higher than that of developed countries (Government of the Russian Federation 2010b).

The new energy efficiency legislation establishes standards for regulating energy consumption to encourage energy savings and amends existing legislation on enforcing energy-saving rules. For example, the law restricts the sale of incandescent light bulbs, introduces the requirement to provide energy efficiency information on product labels, establishes guidelines on mandatory commercial inventories of energy resources, creates standards on energy efficiency of new buildings and sets energy reduction goals. The law also requires an energy audit and metering for all public buildings and establishes that public agencies must reduce their energy and water consumption by 15 percent by 2014 (according to a baseline with comparable conditions).

The Government Program assumes that 44 percent of the projected energy savings will be in buildings and district heating; 22 percent will come from the oil and gas sector, including refining and transportation; 19 percent will come from improved power transmission to homes and municipal institutions like hospitals and schools; and 15 percent will be saved by the industrial sector (Mazneva 2012).

These developments imply that regional and municipal authorities must establish programs locally to increase the use of energy efficient technologies and energy consumption from renewable energy sources for the energy saving targets to be met within the next 15 years. While the total investment requirement is estimated at 9.5 trillion RUB (about $\$ 300$ billion USD), only 695 billion RUB ( $\$ 22$ billion USD) is budgeted to come from the federal and regional budgets. The rest needs to come from private-sector investments (Mazneva 2012).

The newly adopted energy efficiency legislation and programs in Russia create demand for energy efficient products and services. This presents considerable opportunities for interested U.S. energy efficient and environmental technologies companies. This report will introduce market opportunities relevant for U.S. businesses interested in exporting energy efficient products, equipment and services. According to David Johnson, vice-president of Nalco Ecolab, who accompanied a U.S. trade delegation to Russia in June 2012, the potential for the U.S. businesses on Russian energy efficiency market is vast (Mazneva 2012). 


\subsection{Energy Consumption Trends and Opportunities for Energy Efficiency in the Russian Residential Buildings Sector}

Russia is a large country with an inefficient and aging energy infrastructure, which in turn means that there are growing opportunities for energy efficiency products and services. The Government Program "Energy Savings and Energy Efficiency up to 2020" notes that more than 90 percent of capacity of active power stations, 83 percent of residential buildings, 70 percent of water boilers, 70 percent of electric grid technologies and 66 percent of district heating networks were constructed before 1990 (Government of the Russian Federation 2010b). Russia's seven major areas of economic activity - agriculture, forestry, construction, manufacturing, transport, storage and services - are ranked among top 25 most energy intensive in their respective categories globally. Not surprisingly, energy efficiency was identified by then-President Medvedev as one of his top five priorities for modernizing the Russian economy.

Russian buildings are particularly energy intensive, due to inefficient design and the long heating season. A recent International Energy Agency (IEA) study comparing energy use in buildings across countries found that Russian residential buildings use more than twice as much energy to heat a square meter of space as those in Canada, a country with similar geographic and climatic conditions (IEA 2011). The International Finance Corporation (IFC)/World Bank estimated that energy efficiency investments in Russian buildings (residential, commercial and public) could save up to 69 million tonnes of oil equivalent (Mtoe) per year, or 690 million Gcal (IFC and World Bank 2008).

The building sector of Russia possesses the largest potential savings out of all energy consuming sectors (IEA 2011). In this sector, about three-fourth of the energy is consumed by residential buildings (IEA 2010). Most of residential energy consumption is in the form of space heating (58 percent), with district heating supplying three-fourth of residents (IFC and World Bank 2008). Water heating consumes about 25 percent of energy used in residential buildings (Fig 1.1). The remaining 17 percent of overall consumption in residential buildings is cooking (10 percent), appliances (4 percent) and lighting (2 percent) (CENEf 2008).

Figure 1.1 Residential Energy Consumption in Russia.

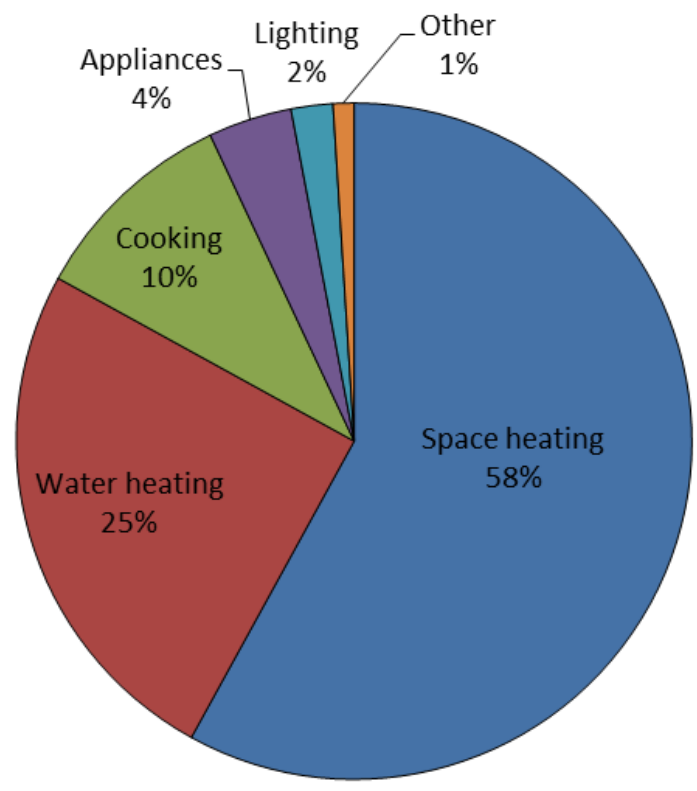

Source: Data adapted from IFC and World Bank 2008. 
The IFC/World Bank and the Center for Energy Efficiency (CENEf) estimate that the residential sector offers the greatest potential for improving energy efficiency in Russia (IFC and World Bank 2008, CENEf 2008). According to the researchers, "the technical potential to reduce energy consumption is 53.4 Mtoe, of which:

- over 80 percent is achievable through investments that are economically viable and

- 46 percent is achievable through investments that are financially viable with current domestic fuel prices."

Most of the potential energy savings come from improvements in space heating and water heating (IFC and World Bank 2008, CENEf 2008).

Russian average heating energy intensity for multi-family, high-rise buildings is 229 $\mathrm{kWh} / \mathrm{m}^{2} /$ year (IFC and World Bank 2008). For new multi-family high buildings, the heating energy intensity is $77 \mathrm{kWh} / \mathrm{m}^{2} /$ year. Rehabilitating existing housing stock can reduce the energy intensity to $151 \mathrm{kWh} / \mathrm{m}^{2} /$ year (IFC and World Bank 2008). The IFC/World Bank authors also note that "A small percentage of the buildings erected after 2000 in compliance with new thermal insulation standards actually meet modern thermal performance and heat efficiency requirements. However, the majority of existing buildings have much lower parameters of space heating efficiency."

The IFC/World Bank also provide evidence of a very strong correlation between energy intensity of water heating and age of buildings with newer and renovated buildings having significantly lower hot water energy intensity. Specifically, buildings built before 1990 have hot water energy intensity between 0.08 and $0.18 \mathrm{Gcal} / \mathrm{m}^{2} /$ year. Renovated buildings of this vintage can achieve 0.06 to $0.08 \mathrm{Gcal} / \mathrm{m}^{2} /$ year. Buildings built between 1990 and 2000 achieve between 0.04 to 0.06 $\mathrm{Gcal} / \mathrm{m}^{2} /$ year and those built after 2000 can achieve below $0.04 \mathrm{Gcal} / \mathrm{m}^{2} /$ year (IFC and World Bank 2008).

Significant potential savings can be obtained by rehabilitating hot water delivery systems, including investments that improve regulation of water temperature and insulation of hot water pipes. Another investment with great potential savings is installation of hot water meters in individual apartments, which can encourage changes in consumer behavior (IFC and World Bank 2008).

The IFC and the European Bank for Reconstruction and Development (EBRD) (IFC/EBRD 2012) discuss the status of current Russian residential housing. The housing stock is estimated at 19.7 million buildings, with 3.2 billion $\mathrm{m}^{2}$ of floor space. Seventy-two percent of that floor space is estimated to be in urban areas. The predominant housing option is multi-family apartment buildings, which number 3.2 million buildings with 2.2 billion $\mathrm{m}^{2}$ of floor space. Most of the apartments are privately owned, although the common spaces are maintained by municipal management companies. IFC/EBRD also state that "The need for modernization is enormous: some 58-60 percent of the country's total multi-family apartment buildings are in need of extensive capital repair, rising to 93-95 percent in those apartment blocks with an average age of not less than 25 years" (IFC/EBRD 2012). 


\subsection{Energy Consumption Trends and Opportunities for Energy Efficiency in the Russian Public and Commercial Buildings Sector}

The other portion of the Russian buildings sector is public and commercial buildings. CENEf (2008) notes that there is no Russian statistical data on this sector, but estimates the total floor space of the sector at 700 to 740 million $\mathrm{m}^{2}$. CENEf also estimates that approximately half of this floor space is the public sector. As with the residential sector, heating and hot water are important end uses and the same energy conservation measures (meters and other hot water efficiency measures) are recommended. Lighting systems in schools are very old and in need of replacement; at the same time, comfort problems (both under- and over-heating) are noted. CENEf also reports issues with building thermal envelopes, particular with windows and interpanel joints. The breakdown of energy use in the public sector is: space heating 60.3 percent, cooking 11.4 percent, lighting 8.6 percent, hot water 7.1 percent and other use 12.6 percent. 


\section{Energy Consumption Trends and Opportunities for Energy Efficiency}

\subsection{Construction Trends in Russia}

Table 2.1 provides information on the total number, total volume and total area of new residential and non-residential buildings in Russia (Rosstat 2011). For residential buildings, there is a consistent increase in the number, volume and floor space of new construction for every year from 2000 to 2008. Volume and floor space fall in 2009, and all three parameters fall in 2010, followed by an increase in 2011. For non-residential buildings, there is a consistent increase in the number, volume and floor space from 2000 to 2009, followed by a drop in 2010 and an increase in 2011. Comparison of the magnitude of the residential and non-residential sectors indicates that new construction in the residential sector in 2011 accounted for 13 times as many buildings, 2.3 times as much volume and 3.6 times the floor area of the non-residential sector.

Table 2.1 New Construction in Russia, 2005-2011.

\begin{tabular}{|l|r|r|r|r|r|r|r|}
\hline & \multicolumn{1}{|c|}{2005} & \multicolumn{1}{c|}{2006} & \multicolumn{1}{c|}{2007} & \multicolumn{1}{c|}{2008} & \multicolumn{1}{c|}{2009} & 2010 & 2011 \\
\hline $\begin{array}{l}\text { Total number of new } \\
\text { buildings (thousands) }\end{array}$ & 141.8 & 159.0 & 209.9 & 224.6 & 233.3 & 216.5 & 223.8 \\
\hline - residential & 131.0 & 148.7 & 194.6 & 208.9 & 217.2 & 201.7 & 210.8 \\
\hline - non-residential & 10.6 & 10.3 & 15.3 & 15.7 & 16.1 & 14.8 & 13.0 \\
\hline $\begin{array}{l}\text { Total volume of new } \\
\text { buildings (million m }{ }^{3} \text { ) }\end{array}$ & 265.4 & 304.2 & 414.1 & 446.2 & 423.6 & 397.4 & 407.7 \\
\hline - residential & 202.2 & 234.4 & 282.1 & 310.9 & 280.8 & 271.8 & 305.6 \\
\hline - non-residential & 63.2 & 69.8 & 132.0 & 135.3 & 142.8 & 125.6 & 102.1 \\
\hline $\begin{array}{l}\text { Total new floor space } \\
\text { (million m }^{2} \text { ) }\end{array}$ & 66.3 & 75.8 & 98.1 & 102.5 & 95.1 & 91.5 & 94.8 \\
\hline - residential & 54.8 & 62.3 & 74.5 & 79.2 & 72.5 & 70.3 & 77.1 \\
\hline - non-residential & 11.5 & 13.3 & 23.6 & 23.3 & 22.6 & 21.2 & 17.6 \\
\hline
\end{tabular}

Source: Data adapted from PMR 2012.

Table 2.2 provides some additional detail on residential apartments and floor area that supplements data in Table 2.1.

Table 2.2 Residential Space Completed (Number of Apartments and Their Total Floor Space), 2005-2010.

\begin{tabular}{|l|r|r|r|r|r|r|}
\hline & 2005 & 2006 & 2007 & 2008 & \multicolumn{1}{|c|}{2009} & \multicolumn{1}{|c|}{2010} \\
\hline Number of apartments completed (thousands) & 515 & 609 & 722 & 768 & 702 & 717 \\
\hline Change (Year-on-year, percent) & & $15.4 \%$ & $15.7 \%$ & $6.0 \%$ & $-9.4 \%$ & $2.1 \%$ \\
\hline Total new residential space (million $\mathrm{m}^{2}$ ) & 43.5 & 50.6 & 61.2 & 64.1 & 59.9 & 58.4 \\
\hline Change (y-o-y, percent) & & $16.3 \%$ & $21.0 \%$ & $4.7 \%$ & $-6.6 \%$ & $-2.5 \%$ \\
\hline
\end{tabular}

Source: Data adapted from Rosstat 2011. 
Table 2.3 provides an estimate of the Russian construction market in the years 2003 to 2012 . The Russian construction industry bottomed out in mid-2009 and has since rebounded. These data reinforce the trends shown in Table 2.1.

Table 2.3 Construction and Assembly Output (Value and Year-on-Year (Y-O-Y) Change), 2003-2010.

\begin{tabular}{|l|c|c|c|c|c|c|c|c|}
\hline & 2003 & 2004 & 2005 & 2006 & 2007 & 2008 & 2009 & 2010 \\
\hline RUB billion & $1,042.7$ & $1,313.5$ & $1,711.7$ & $2,350.8$ & $3,293.3$ & $4,528.1$ & $3,998.3$ & 4,206 \\
\hline $\begin{array}{l}\text { Real change } \\
\text { (percent, y-o-y) }\end{array}$ & $12.8 \%$ & $10.1 \%$ & $10.5 \%$ & $18.1 \%$ & $18.2 \%$ & $12.8 \%$ & $-13.2 \%$ & $-0.6 \%$ \\
\hline
\end{tabular}

Source: Data adapted from PMR 2012 and Rosstat 2011.

Even though the recent global economic crisis has created challenging conditions for most markets, the Russian construction sector is expected to grow. This is largely attributed to increase in spending for infrastructure development and high demand for residential properties. As a result, most construction companies saw an increase in their sales and orders in 2010. This trend has been maintained in the first half of 2012 (PMR 2012). According to Obetkon (2012), in Q1 of 2012, the value of completed projects increased by 5.2 percent to 793.9 billion RUB ( $\$ 26.5$ billion USD) compared with the previous year.

Another positive trend is the growth of the mortgage market. As banks have become more willing to lend for residential developments, more projects have been resumed or started (PMR 2012). This can also help grow the market for energy efficiency products.

Factors impacting the construction market in Russia include the legislation and policy context. The Russian legislation on housing development remains fairly complicated from an investor's point of view, although measures are being taken to change that situation. For instance, planned simplification of procedures on residential construction will reduce the time to the start of construction to from 946 to 180 days. On the other hand, the 2011-2015 Housing Program envisions that housing construction will grow by 50 percent by 2015 , to 90 million $\mathrm{m}^{2}$. Over its five-year span, the program is expected to create 370 million $\mathrm{m}^{2}$ of housing (Obetkon 2012). In 2012 alone, the Russian Government is certain that 67 million $\mathrm{m}^{2}$ of housing will be built, more than in the record 2008. In Q1 of 2012, so far 111,800 new housing units were built, with the total floor space of 9.8 million $\mathrm{m}^{2}$ (Obetkon 2012, PMR 2012). In addition, many unfinished residential buildings are awaiting completion, with a total floor area of 30 million $\mathrm{m}^{2}$ as of 2010 (Table 2.4).

Table 2.4 Data on Unfinished Construction of Residential Buildings in Russia, 1995-2010 $\left(\right.$ Million $\mathrm{m}^{2}$ ).

\begin{tabular}{|l|c|c|c|c|c|c|c|c|}
\hline Year & 1995 & 2000 & 2005 & 2006 & 2007 & 2008 & 2009 & 2010 \\
\hline Total area $\left(\right.$ million $\left.\mathrm{m}^{2}\right)$ & 90.1 & 45.2 & 35.0 & 36.1 & 39.2 & 39.5 & 33.9 & 29.7 \\
\hline
\end{tabular}

Source: Data adapted from Rosstat 2011.

For non-residential construction, Tables 2.5 and 2.6 summarize historical and recent construction data on public buildings. 
Table 2.5 Data on Construction of Social and Cultural Buildings in Russia.

\begin{tabular}{|r|l|l|r|r|r|}
\hline Year & $\begin{array}{l}\text { General } \\
\text { education } \\
\text { institutions } \\
\text { (schools), } \\
\text { thousands of } \\
\text { seats }\end{array}$ & $\begin{array}{l}\text { Preschool } \\
\text { educational } \\
\text { institutions } \\
\text { (nursery } \\
\text { schools), } \\
\text { thousands of } \\
\text { seats }\end{array}$ & $\begin{array}{l}\text { Hospitals, } \\
\text { thousands } \\
\text { of beds }\end{array}$ & $\begin{array}{l}\text { Outpatient clinics } \\
\text { and departments, } \\
\text { thousands of } \\
\text { visits per shift }\end{array}$ & $\begin{array}{l}\text { Cultural } \\
\text { institutions } \\
\text { (clubhouses), } \\
\text { thousands of } \\
\text { seats }\end{array}$ \\
\hline 1970 & 774.4 & 261.6 & 36.6 & 68.2 & 404.2 \\
\hline 2000 & 53.5 & 3.0 & 1.5 & 3.3 & 9.6 \\
\hline 2005 & 27.9 & 0.9 & 0.9 & 2.6 & 5.7 \\
\hline 2006 & 73.4 & 20.0 & 9.0 & 22.5 & 12.9 \\
\hline 2007 & 88.3 & 26.1 & 7.9 & 31.7 & 12.3 \\
\hline 2008 & 67.6 & 28.3 & 8.1 & 25.3 & 8.4 \\
\hline 2009 & 77.2 & 19.6 & 6.3 & 22.5 & 11.2 \\
\hline 2010 & 67.3 & 23.0 & 8.7 & 27.3 & 13.4 \\
\hline
\end{tabular}

Source: Data adapted from Rosstat 2011.

Table 2.6 Data on Construction of Buildings Used for Higher and Vocational Education (Thousand $\mathrm{m}^{2}$ ).

\begin{tabular}{|r|r|r|r|r|}
\hline Year & $\begin{array}{l}\text { Higher education } \\
\text { premises }\end{array}$ & $\begin{array}{l}\text { Intermediate vocational } \\
\text { education premises }\end{array}$ & $\begin{array}{l}\text { Beginning vocational } \\
\text { education premises }\end{array}$ \\
\hline 1970 & 419.2 & 244.3 & 48.7 \\
\hline 2000 & 105.6 & 18.2 & 0.6 \\
\hline 2005 & 161.3 & 11.5 & 0.3 \\
\hline 2006 & 161.0 & 23.8 & 0.7 \\
\hline 2007 & 151.8 & 22.7 & 1.3 \\
\hline 2008 & 216.2 & 38.5 & 0.08 \\
\hline 2009 & 154.6 & 11.7 & 1.9 \\
\hline 2010 & 219.7 & 60.4 & 1.2 \\
\hline
\end{tabular}

Source: Data adapted from Rosstat 2011.

It should be noted that Moscow is one of the prime areas for construction and development. It is expected that over the next 10-15 years, 45 million $\mathrm{m}^{2}$ of offices and 60 million $\mathrm{m}^{2}$ of housing will be constructed in the Moscow greater area (PMR 2011).

Currently, the major developers of residential and non-residential construction in Russia are PIK Group, Inteco, SU-155, AFI Development, Midland Development, Sistema Hals and LSR Group (PMR 2012). 


\subsubsection{Information on Building Energy Efficiency Projects in Russia}

Several programs exist in Russia on energy efficient building construction and retrofit. One of the most active is the UN's Global Environmental Facility (GEF) ${ }^{1}$. An example of a GEF-funded project is a pilot on energy efficient lighting, a $\$ 2.5$ million investment in schools in Moscow and several northwestern regions. It is expected that the investment will reduce the schools' electricity bills by a minimum of 30 percent. Another project is planned in Sarov (Nizhegorod Region) to re-equip the town's lighting, thereby reducing energy losses (U.S. Commercial Service 2012).

Together with the UN Development Programme, GEF is also implementing an energy efficiency construction project in Pskov Region. The project aims to develop a normative and legal basis for implementing energy efficiency programs and establishing a model for managing institutional energy efficiency for municipalities.

Other selected large-scale energy efficiency projects in residential and public buildings in Russia involving international aid are summarized in Table 2.7, based on the information available at projects' web-sites.

In addition to energy efficiency projects in buildings implemented through international programs, Russia has a wide range of such projects that were supported solely by Russian federal or local authorities or private investors. According to the Government Program "Energy Savings and Energy Efficiency up to 2020", federal and regional authorities plan to spend about 695 billion RUB ( $\$ 22$ billion USD) on energy efficiency projects (Mazneva 2012). By law, each region must submit annually its energy efficiency strategy and can apply for co-financing for its implementation. In 2011, 55 out of 83 Russian regions received co-financing support, totaling in 5 billion RUB ( $\$ 162$ million USD) (Caprio 2012). Priority projects included energy audits, metering, small-scale generation, upgrading lighting systems, utility subsidies for the poor under the conditions of increasing tariffs and educational programs.

There are numerous examples of locally funded projects implemented throughout the country (Ecological Systems 2012, Kanev 2011), such as in the cities of Perm, Cherepovets, Orenburg, Ryazan, Vladimir, Volhov, Khabarovsk and others. One such project implemented in Irkutsk aimed to replace obsolete energy efficiency district heating equipment (Kotov et al. 2001). In Petrozavodsk city, a complete energy efficient city district was built in accordance with all modern energy efficiency standards (Skripitsyn and Shmaenik 2003). A rural energy efficiency school in Yaroslavl Region was built using thermal pumps and latest energy efficiency innovations (Vasiliev and Krundyshev 2002). Irkutsk city adopted a policy that all future buildings will conform to energy efficiency standards in buildings (Ecological Systems 2011). CENEf reported on Federal Program "Energy Efficiency in Educational Sector of Russia" during 1999 - 2005 (Bashmakov 2005). A total of \$40 million USD worth of energy efficiency measures and activities has been implemented in 763 Russian schools.

\footnotetext{
${ }^{1}$ The GEF is a facility of the United Nations Framework Convention on Climate Change (UNFCC). United Nations Environment Programme (UNEP), United Nations Development Programme (UNDP), and the World Bank serve as implementing agencies.
} 
Maksimenko and Vrobleskiy (2005) report that, in general, the Russian market for intelligent energy efficient buildings is focused mainly in Moscow, St. Petersburg and a number of large industrial centers. However, in recent years there has been a tendency to promote development in the regions. According to several studies the authors were referring to, the annual growth of the intelligent energy efficient building market is around 20-25 percent.

Energy efficiency is one aspect of green buildings. Although, according to the U.S. Commercial Service (2012), green buildings are still in their infancy in Russia, they are increasing in popularity as consumer energy prices rise, and as people and organizations become more conscious of spending and the positive effects of a healthier environment. Following approval of the new Russian Federal Law on energy efficiency, the green building community has become more active in promoting awareness of green building concepts and supporting expansion of green standards.

The focus of green building construction in Russia is the Russian Green Building Council (RuGBC), created in November 2009. Russia's Ministry of Natural Resources is collaborating with RuGBC. The RuGBC currently has 120 members, works with developers interested in green building certification and provides support and links to several international green building rating systems, including the U.S. Green Building Council's Leadership in Energy and Environmental Design (LEED), the UK-based BREEAM (Building Research Establishment Environmental Assessment Method) and the German Sustainable Building Council's DGNB (Deutsche Gesellschaft für Nachhaltiges Bauen e.V.). As U.S. Commercial Service reports "The RuGBC has also supported the development of green standards and sustainable design and construction methods for the Sochi 2014 Winter Olympic Games, resulting in several international fact-finding missions and seminars, as well as the adoption of BREEAM and LEED as standards for top venues" (U.S. Commercial Service 2012).

Russia also recently issued two green building standards. One was designed by the Russian Association of Engineers for Heating, Ventilation, Air-Conditioning, Heat Supply and Building Thermal Physics (ABOK), which is an Associate Society member of American Society of Heating, Refrigerating and Air-Conditioning Engineers (ASHRAE) (ASHRAE 2012). The other was developed by experts at Russian Sustainable Architecture and Building Council (RSABC) and was approved by the Russian National Union of Architects, Ministry of Regional Development and DGNB experts (RSABC 2012).

Some buildings have also been certified internationally. Namely, two buildings - a retail and office building in Moscow Ducat and Swedish SKF bearing factory in Tver Region - received BREEAM's "very good" and LEED NC v.2.2 Gold, respectively. As of 2012, another 14 buildings were applying for BREEAM certification, six were applying for LEED and several pilots were considered for DGNB (U.S. Commercial Service 2012).

In addition to green certification, buildings with "green features" have been increasing in popularity, which is an essential milestone in transformation of Russia's green building market. 
Table 2.7 Additional International Energy Efficiency Projects in Russian Buildings.

\begin{tabular}{|c|c|c|c|c|c|}
\hline $\begin{array}{l}\text { Project } \\
\text { Name }\end{array}$ & Brief Description & $\begin{array}{l}\text { Start } \\
\text { year }\end{array}$ & Funder(s) & Implementer(s) & $\begin{array}{l}\text { Approximate Total } \\
\text { Project/Activity } \\
\text { Funding in USD/ } \\
\text { Specific Annual } \\
\text { Funding Share } \\
\text { (US\$ or percent } \\
\text { US\$): }\end{array}$ \\
\hline $\begin{array}{l}\text { Improving } \\
\text { Efficiency in } \\
\text { Public } \\
\text { Buildings in } \\
\text { the Russian } \\
\text { Federation - } \\
\text { under the } \\
\text { Energy } \\
\text { Efficiency } \\
\text { Umbrella } \\
\text { Program }\end{array}$ & $\begin{array}{l}\text { The proposed EBRD-GEF project is designed to reduce } \\
\text { greenhouse gas emissions in Russia by improving } \\
\text { efficient use of energy in Public Buildings such as } \\
\text { kindergartens, schools, hospitals, and public offices. By } \\
\text { combining technical assistance with financing, the } \\
\text { EBRD aims to help local authorities overcome common } \\
\text { obstacles to financing energy efficiency improvements } \\
\text { such as allocation of resources for energy audits and } \\
\text { project preparation, tendering procedures, and } \\
\text { management of larger-scale programs that may need } \\
\text { additional dedicated resources. By the end of the } \\
\text { project, a sufficiently large number of Russian cities } \\
\text { will be using EPC mechanisms (target } 5 \text { cities) and } \\
\text { numerous other Russian cities will have been supported } \\
\text { or trained (target at least } 50 \text { ) that they can then build on } \\
\text { this experience and continue the development of the } \\
\text { market without outside influence. Investment barriers } \\
\text { will be addressed through credit for municipal energy } \\
\text { efficiency investments and the introduction of the sale } \\
\text { of receivables (forfeiting) as a means of energy } \\
\text { efficiency financing. Direct emission reductions from } \\
\text { the project, over 20-year equipment lifetimes is }\end{array}$ & 2008 & $\begin{array}{l}\text { GEF Trust } \\
\text { Fund }\end{array}$ & EBRD & $\begin{array}{l}\text { Approximate Total } \\
\text { Project/Activity } \\
\text { Funding in USD: } \\
\$ 78,007,675 \text { (total } \\
\text { project cost) } \\
\text { Specific Annual } \\
\text { Funding Share (US\$ } \\
\text { or percent US\$): } \\
\$ 9,209,075 \text { (GEF } \\
\text { grant) }\end{array}$ \\
\hline
\end{tabular}

\footnotetext{
${ }^{2}$ This information was taken directly or adapted from GEF $2010 \mathrm{~b}$.
} 


\begin{tabular}{|c|c|c|c|c|c|}
\hline & estimated to be 3.8 million tones. & & & & \\
\hline $\begin{array}{l}\text { Investments } \\
\text { into Energy } \\
\text { Efficient } \\
\text { Renovations } \\
\text { of } \\
\text { Residential } \\
\text { Multi-family } \\
\text { Buildings in } \\
\text { Russia }^{3}\end{array}$ & $\begin{array}{l}\text { The goal of the project is to facilitate investments into } \\
\text { energy efficient renovations of residential multi-family } \\
\text { buildings in Russia and avoid CO2 emissions by } \\
\text { creating an effective legal and institutional platform to } \\
\text { support Russian home owner associations and housing } \\
\text { management companies in getting access to finance for } \\
\text { the purpose of improving energy efficiency of the } \\
\text { country's existing housing stock. This five-year, } \\
\text { advisory services Project will take on a programmatic } \\
\text { approach and will focus on the following key objectives: } \\
\text { Develop regulatory and legal environment addressing } \\
\text { key legal and regulatory issues, in particular (i) the } \\
\text { framework for energy efficiency in residential buildings } \\
\text { and (ii) legislation enabling local home owner } \\
\text { associations and management companies to access } \\
\text { finance for the purpose of improving energy efficiency } \\
\text { in multifamily buildings. Develop and market } \\
\text { financially viable residential energy efficient products } \\
\text { by working with pilot Russian banks. Increase capacity } \\
\text { and awareness about residential energy efficiency } \\
\text { among key market stakeholders. The Project will be } \\
\text { implemented jointly by IFC and EBRD, and will allow } \\
\text { both entities to closely coordinate all sector work, } \\
\text { leverage resources, and achieve greater impact by } \\
\text { joining efforts. By partnering with EBRD, IFC further } \\
\text { enhances its additionality as EBRD's involvement will } \\
\text { provide additional investments in energy efficiency in } \\
\text { the Russian residential sector and will allow each } \\
\text { agency to capitalize on its strengths in addressing sector }\end{array}$ & 2010 & $\begin{array}{l}\text { IFC, } \\
\text { EBRD }\end{array}$ & $\begin{array}{l}\text { Open Joint Stock } \\
\text { Company } \\
\text { Commercial } \\
\text { Bank "Center- } \\
\text { invest"; Finnish } \\
\text { Ministry of } \\
\text { Employment and } \\
\text { the Economy, } \\
\text { the Finnish } \\
\text { Ministry for } \\
\text { Foreign Affairs, } \\
\text { and the Global } \\
\text { Environmental } \\
\text { Facility (GEF) }\end{array}$ & $\begin{array}{l}\text { Approximate Total } \\
\text { Project/Activity } \\
\text { Funding in USD: } \\
50,000,000 \text { (total } \\
\text { IFC Investment) }\end{array}$ \\
\hline
\end{tabular}

\footnotetext{
${ }^{3}$ This information was taken from PNNL's database IBEX (PNNL 2012).
} 


\begin{tabular}{|c|c|c|c|c|c|}
\hline & barriers. & & & & \\
\hline $\begin{array}{l}\text { GEF Project } \\
\text { to Boost } \\
\text { Urban } \\
\text { Housing } \\
\text { Energy } \\
\text { Efficiency }\end{array}$ & $\begin{array}{l}\text { A } \$ 9.6 \text { million project to improve energy efficiency of } \\
\text { houses in Russia. The initiative is part of a } \$ 722 \text { million } \\
\text { five-year program implemented jointly by EBRD and } \\
\text { IFC, the private sector arm of the World Bank Group. } \\
\text { The project will aim at improving energy efficiency of } \\
\text { housing stock, addressing financial, legislative and } \\
\text { technical issues which are the three main barriers to } \\
\text { energy efficiency in existing, residential buildings in } \\
\text { Russia. }\end{array}$ & 2010 & $\begin{array}{l}\text { EBRD; } \\
\text { IFC }\end{array}$ & GEF & $\begin{array}{l}\text { Approximate Total } \\
\text { Project/Activity } \\
\text { Funding in USD: } \\
\$ 722,000,000 \text { total } \\
\text { Estimated Total } \\
\text { Funding Category: } \\
\text { very large (multi- } \\
\text { project umbrella } \\
\text { activity or project } \\
\text { that appears to be } \\
>\$ 5 \text { million) }\end{array}$ \\
\hline
\end{tabular}

\footnotetext{
${ }^{4}$ This information was taken from GEF 2010a.
} 


\subsubsection{Building Energy Efficiency Projects in Moscow}

An Energy Saving Program for Moscow for the years 2012-2016 and until 2020 was approved in 2011 (U.S. Commercial Service 2012). The program is described as "an integral cross-sectoral program interconnecting energy efficiency efforts of all Moscow authorities, institutes, enterprises and businesses." The program includes " 40,000 residential houses and 75 nonresidential buildings. The target of the program is to reduce energy intensity by 2020 by no less than 40 percent compared to 2007." According to Russian statistics, Moscow has the lowest energy intensity of all Russian regions and geographical sub-units; however "energy intensity of residential and communal utilities of Moscow is lagging behind the largest cities in the world, which testifies to the high potential in the sector" (U.S. Commercial Service 2012). About 201.8 billion RUB ( $\$ 6.5$ billion USD) have been allocated for the program implementation, where 4 billion RUB ( $\$ 160$ million USD) comes from the city budget and about 180 billion RUB ( $\$ 5.8$ billion USD) from non-budgetary sources.

According to Filatov (2009), Moscow can be considered a leader in energy efficiency for several reasons. It has the largest market in the country to promote energy efficiency equipment, and consumers willing to pay to install measures in their apartments. In addition, it was the first region in Russia to develop a special program "Energy in Moscow in 2009-2011 and to 2020," which also provides for technical measures and various factors to stimulate energy efficiency.

Moscow as a city consumes about 90 million Gcal of thermal energy per year and about 35 billion $\mathrm{kWh}$ of electricity. The largest consumer of energy (in terms of fuel) is the residential sector, accounting for 52 percent. In fact, electricity consumption by households has doubled in the past decade. The industrial and construction sectors account for 18 percent, but their share has dropped significantly in recent years. The federal and the budget sphere make up an additional 15 percent of Moscow's electricity consumption and trade and services another 10 percent (Filatov 2009). Thus, the residential sector presents one of the largest opportunities in the Moscow Region for engagement in energy efficiency projects. The building sector more broadly is also an important source of opportunity.

The city has many energy efficiency projects in residential buildings currently underway. Projects may be separated by two different streams: new buildings that comply with all energy efficiency standards according to the newly adopted energy efficiency legislation, and retrofit projects to improve the efficiency of older buildings.

The first category includes projects like completion of Vorontsovo residential complex (Ligun 2005), Nikulino district residential buildings (Khromkin 2000), New Circle of Moscow and Moscow-City residential complexes (Maksimenko and Vroblevskiy 2005), North Izmailovo complex implemented jointly with the government of Moscow and Saint Gobain ISOVER company (ISOVER 2012). The planned expansion of Moscow City boundaries will also create additional demand for energy efficient construction, as the government announced that energy efficiency is a big priority (see Table 2.10 for more information).

The second category includes projects like energy efficiency measures taken in the office building of Moscow Department of Fuel and Energy (Konstantinov 2012). 


\subsubsection{Building Energy Efficiency Projects in St. Petersburg}

Some of the energy efficiency projects underway in St. Petersburg are described below. They can be separated on those that emphasize reducing losses during energy transport and those that concentrate on energy efficiency improvements in residential buildings. The first group of projects includes reduction of heat and energy losses in boilers, pipelines and service equipment of the city (Administration of the City of St. Petersburg 1999, Delyukin et al. 2002). The second group of projects focuses on the residential sector and includes a pilot project to increase energy efficiency in a typical 1980s residential building, which has been implemented with the support of St. Petersburg City Administration and the Federal Ministry of Urban Development of Germany (Ecological Systems 2012). Also, this group includes a project that aims to supply and install energy efficient lighting equipment for three houses in the city (Energy and Industry of Russia 2012); as well as another project to install city-wide energy efficiency LED lighting equipment (RIA Novosti 21Feb. 2012).

\subsubsection{Energy Efficiency Projects in Chelyabinsk}

Chelyabinsk Region has made some advanced steps in designing and implementing an energy efficiency program and its openness and commitment to investors. According to adopted Chelyabinsk energy efficiency regional program, the region puts an emphasis on reducing heat and energy losses from boiler plants and related networks. There is an ongoing project "The implementation of energy efficiency measures at Chelyabinsk Electrometallurgical Works, OJSC" implemented under JI mechanisms (UNFCCC 2012). Data on green building projects in Chelyabinsk is not widely available. However, based on the energy efficiency legislation adopted by Chelyabinsk Region, following energy efficiency activities are implemented or planned in the region: ${ }^{5}$

\section{Measures for boiler plants}

- Energy audits of district heating enterprises of Chelyabinsk Region at least once in 5 years;

- Decommissioning of 138 inefficient boiler plants that have exhausted service life, by increasing the share of heating and power plants in heat generation and decentralizing heat supply;

- Upgrading of 395 boiler plants, by using modern energy-efficient equipment;

- Construction of 106 new boiler plants using advanced technologies with fuel efficiency not less than 85 percent for boiler plants operating on solid fuel, not less than 90 percent for boiler plants operating on liquid fuel, and not less than 92 percent for gas-fired boiler plants;

- Organization of heat and power cogeneration at 42 boiler plants through the use of disposable steam pressure drop at steam boilers to generate electricity sufficient to cover their own needs; gas turbine units in gas-fired boiler plants to generate electricity in connection with heat demand, the use of gas-and-piston units to generate electricity and heat for own needs, as well as through construction of small-sized heat and power plants both gas-fired and biomass-fired at municipal utilities, to produce 2 billion $\mathrm{kWh}$ of electric power by 2020 .

\footnotetext{
${ }^{5}$ This information is based on Energosberezheniye report to PNNL (2012).
} 
- Boiler plant upgrades include substitution of boilers by new reliable models with improved performance and selection of equipment with quickly adjustable output to match changing load requirements due to automated consumption control systems.

\section{Network-related measures}

- Construction of $154 \mathrm{~km}$ of new heat supply networks using the latest technologies;

- Replacement of 2,609 $\mathrm{km}$ of heat supply networks using new modern energy-efficient equipment;

- Decommissioning of 1,019 $\mathrm{km}$ of networks (also due to decentralization).

\section{Residential buildings}

- Energy audit;

- Optimization of fuel and energy resources consumption;

- Upgrading building-level heat and water supply equipment;

- Improvement of buildings thermal performance, including by means of overhauls.

\subsubsection{Mechanisms for Financing Energy Efficiency Projects in the Russian Building Sector}

Availability of financing for energy efficiency projects depends on several factors, including whether a project involves buildings in the private/commercial sector, residential sector or the public domain, such as government agencies, schools, hospitals and others. Financing for new construction and renovations in private and commercial buildings is available through private banks, and this financing can also be used for energy efficiency measures.

For residential projects, much like in the U.S., options exist for customers to take on mortgages to pay for apartments and renovations when the home is used as collateral and the borrower has adequate income. Incorporating energy efficiency measures for new construction is relatively easy, but even for small-scale retrofits projects, banks are beginning to develop financing packaging. Thus, Sberbank, Russia's largest bank, plans to unroll programs for financing residential window replacement and announced an "Energy Efficiency" credit line for citizens (Sberbank 2012). The challenge for this sector is capturing energy savings for the whole façade. Most Russians live in large, multi-family apartment buildings. While most apartments are privately owned, homeowners associations are not yet common in Russia, and thus, there is no organizing force to take on larger-scale retrofit projects. However, there are examples of such projects in the residential sector with government's involvements. In Tyumen and Kazan, Sberbank partnered with municipal governments to install meters and controls in several residential neighborhoods, and implementation of further energy efficiency measures is planned for the future (Sberbank 2012). 
Most social services and infrastructure are run by the municipal, regional or federal governments. Federal law now requires that public buildings reduce energy consumption by $15 \%$ by the end of 2014, with additional energy efficiency improvements by 2020. Administrators of public buildings, thus, have been experiencing increasing pressure to improve their buildings' energy efficiency (Evans et al. 2012). While there are some federal and regional grants to help finance energy efficiency projects in the public sector, they cover only a small share of the need. The Federal Law on Energy Efficiency and the regulations adopted to implement it lay out procedures to use energy performance contracting to attract private investment to this sector. Most of the projects implemented to date are either small-scale projects, or focused on municipal street lighting. The Russian government is trying to increase the scale of projects by modifying the performance contracting rules to make further energy efficiency improvements.

A substantial portion of financing for municipal energy efficiency projects in the former USSR in the past 15 years has come from International Financial Institutions (IFIs), such as the European Bank for Reconstruction and Development (EBRD), the European Investment Bank (EIB), the World Bank, the International Finance Corporation (IFC) and Nordic Environment Finance Corporation (NEFCO). Some of the programs these institutions offer are described in Appendix A.

\subsubsection{Performance Contracting}

Performance contracting is a good option when energy-cost savings are an inherent result of a project. A performance contract is established between the municipality and the provider of energy efficiency service. Energy service provider could be in form of the energy service company (ESCO), private consultancy or NGO. In a performance contracting, "goods and services associated with the project are paid for with the energy-cost savings accrued from it, allowing the municipality to finance improvements without incurring any upfront costs" (ASE 2007). "ESCO's provide the following services: investment grade energy audits, calculation of baseline energy consumption, identification of energy saving measures, design of energy saving projects, installation and maintenance of new energy efficient equipment, training of technical personnel in a facility and monitoring resulting energy savings" (ASE 2007).

In the former USSR, as in the US, it is common for an ESCO to arrange for a third party financing from a commercial bank, corporate funds or other financial institution. Commercial credit is usually more expensive, meaning the interest rates are higher, than funding available to public agencies. Further, an ESCO's internal corporate funds can be limited and require certain rates of return for corporate shareholders (Evans et al. 2012). "Another option is for the municipality to secure the financing, which may be the desired route where government agencies are offering discounted rates and relaxed lending criteria to municipalities" (ASE 2007).

The municipality can start negotiating the project implementation contract with the ESCO after the energy audit has been conducted and the target efficiency projects goals have been set. After performance contracting has been signed, ESCO (or other type of firm) is compensated based on actual energy savings resulting from the project implementation. 


\subsection{Types of Energy Efficient Technologies and Materials Used in the Russian Building Energy Efficiency Sector}

\subsubsection{Heating Ventilation and Air Conditioning (HVAC) and Controls}

Russia's geographical location and climate dictate a strong demand for heat. However, consumption of air conditioning and ventilation has also been on the rise. Two factors in particular, contribute to that rise: growing incomes and, therefore, demand for comfort in buildings; and hotter summers in recent years (IEA 2011). As the new Russian legislation mandates improvements in energy efficiency, this sector is likely to see a surge in demand for HVAC equipment and controls.

\subsubsection{Heating}

The Russian heat sector accounts for a third of the country's primary energy consumption and presents considerable opportunities for U.S. businesses. IEA's data for 2008 estimate Russia's heat consumption as 114 Mtoe, equal to the total final energy consumption of Mexico (IEA 2010). Out of this, about 78 percent is generated by district heating, a system of transmitting heat, usually in the form of hot water, from a centralized boiler or cogeneration plant through a network of pipes (Nekrasov et al. 2012). The remaining 22 percent is produced by individual boilers, gas heaters, traditional stoves, etc. Demand for both district heating systems technologies and individual boilers is expected to grow.

A little over half of heat from district heating is generated by cogeneration plants; 66,000 boiler houses generate the remainder (Nekrasov et al. 2012, McKinsey \& Company 2009). The share of boilers has been increasing over the past years. Gas is the primary fuel source in heat production (66 percent), but coal and coal products are also significant (21 percent) (IEA 2010).

As acknowledged by the Russian Government, about 70 percent of Russian district heating infrastructure needs to be replaced in the near future (IEA 2011, Ministry of Energy of the Russian Federation 2010). Russia has the world's largest, but also oldest district heating infrastructure, with most of it -70 percent of water boilers and 66 percent of district heating networks - having been constructed before 1990 (Government of the Russian Federation 2010b). Not surprisingly, the average heat boiler efficiency is about 73 percent (ECE 2010), while production efficiency in district heating systems in Western Europe is 85 to 95 percent (IEA 2004). State-of-the-art technologies could revamp Russia's district heating system, saving the government and consumers billions of dollars and avoiding many emissions. However, the sector is not without challenges. At present, tariffs are set at artificially low levels, making investments for district heating suppliers difficult to afford. Recently introduced legislation has promising signs that this problem might be soon addressed.

The inefficiency of district heating has led some consumers to switch from district heating to individual boilers. This is particularly the case for industrial facilities, which often pay higher tariffs for heat due to cross-subsidizing policies aiming to protect residents from high heat prices. Studies report that total final consumption of heat decreased by 54 percent among the industrial consumers between 1993 and 2007 (Korppo and Korobova 2012). A large share of that is due to 
industry switching to producing heat onsite. Over the same time period, combined consumption of residential, commercial and public consumers also fell by 33 percent (Korppo and Korobova 2012).

The demand for heat metering and controls in Russia has been growing steadily, largely based on the new regulatory requirements. Metering and control solutions are somewhat challenging for older buildings, which are not designed to have meters and controls. Vertical-stand pipe systems in such buildings connect apartments on multiple floors, but are not connected to each other within one apartment. In such buildings, the most practical metering option is to install buildinglevel meters. About 30 percent of buildings now have heat meters at least at the building level, and most new construction has apartment-level meters. Controls within the building are often still simple radiator controls, but this is changing, particularly in high-end construction, and increasingly in public buildings as well.

\subsubsection{Cooling}

Although heat dominates the Russian HVAC market, the demand for air conditioning and ventilation has been on the increase. As average incomes have been growing, particularly in large cities, Russians demanded more air conditioning and ventilation. Currently, ownership of air conditioners remains low, at six per 100 households (IEA 2011). But recent years have seen a surge in demand for air conditioning, also partially attributed to heat waves and climate change. For example, summer of 2010 is considered the hottest on record in Russia, when the average temperature was $6^{\circ} \mathrm{C}$ higher than usual. The following year, albeit not as hot, continued the trend of above-average temperatures.

Litvinchuk's Marketing Agency (2001) reported that the Russian sale of air conditioning equipment had experienced the highest growth rates in Europe. Initially, room air conditioners were in greatest demand, but since about 1998 central air conditioning systems and ventilation equipment have become increasingly popular, with sales increasing by 25 percent compared to the previous season for the past five years in a row.

Moscow accounts for 50 percent of the Russian central air conditioning system ownership, while St. Petersburg makes up just under 20 percent. Outside of these cities, the market is smaller, in part because of the cool summers, but sales are nonetheless growing at a very rapid pace.

The cooling equipment market has not experienced many changes since the late 1990s. The three leaders of the market are TRANE, YORK and CARRIER. However, their share has been falling, while new brands have been appearing. Domestic manufacturers in Russia, such as VTS Clima and VEZA, have a growing position on the market, possibly because of their lower prices (Litvinchuk 2001).

Domestic production has mostly focused on air pipes, air gates, mufflers and valves. However, more recently, Russian companies have been setting up manufacturing of modern duct ventilators, albeit with use of foreign impellers and engines (Litvinchuk 2001). 


\subsubsection{Lighting}

According to GEF (2009), in 2007 annual power demand for lighting in Russia was 57.5 TW, corresponding to electricity consumption of $137.5 \mathrm{TWh}$, or 14 percent of national electricity consumption and annual $\mathrm{CO}_{2}$ emissions of $69 \mathrm{Mt}$.

Table 2.8 shows energy consumption for lighting by economic sector as well as the estimated energy saving potential. As can be seen in Table 2.8, commercial and industrial buildings account for more than 50 percent of lighting energy consumption.

Table 2.8 Energy Consumption for Russian Lighting Sector and Technical Potential for Energy Savings.

\begin{tabular}{|l|c|c|c|c|}
\hline $\begin{array}{l}\text { Type of lighting } \\
\text { equipment }\end{array}$ & $\begin{array}{l}\text { Established } \\
\text { capacity } \\
\text { (GW) }\end{array}$ & $\begin{array}{l}\text { Electric energy } \\
\text { consumption } \\
\text { (GWh/year) }\end{array}$ & $\begin{array}{l}\text { Potential energy } \\
\text { saving } \\
\text { (GWh/year) }\end{array}$ & $\begin{array}{l}\text { Released } \\
\text { capacity } \\
\text { (GW) }\end{array}$ \\
\hline $\begin{array}{l}\text { Industry and commercial } \\
\text { buildings }\end{array}$ & 28 & 85,000 & 30,000 & 10 \\
\hline $\begin{array}{l}\text { Public, educational and } \\
\text { state buildings }\end{array}$ & 8 & 12,000 & 5,000 & 3 \\
\hline Street lighting & 1.5 & 4,500 & 2,000 & 0.7 \\
\hline Residential sector & 15 & 20,000 & 13,000 & 10 \\
\hline $\begin{array}{l}\text { Agricultural sector, } \\
\text { including rural population }\end{array}$ & 5 & 16,000 & 7,000 & 2.5 \\
\hline Total & 57.5 & 137,500 & 57,000 & 26.2 \\
\hline
\end{tabular}

Source: Data adapted from GEF 2009 and Zissis et al. 2010.

Figure 2.1 shows that penetration of energy efficient lighting products and technologies is extremely low across all sectors. Of the estimated 1 to 1.2 billion lighting sources in Russia, more than half are incandescent lamps (97 percent of all lighting sources in the residential sector and up to 20 percent in the industrial and commercial sectors) (GEF 2009). 
Figure 2.1 Lighting Technologies Used in Russia.

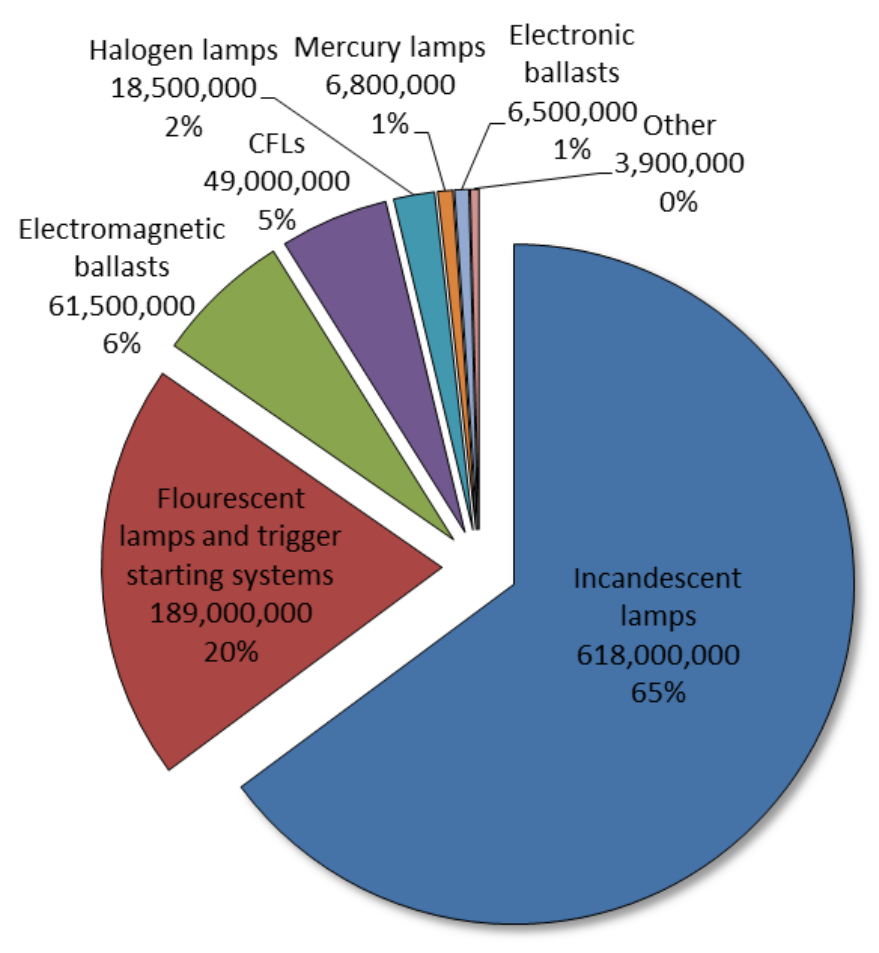

Source: Data adapted from GEF 2009.

According to GEF (2009), "lighting control systems that are widely used today in Western countries are almost absent from the Russian market; and that electronic ballasts for linear fluorescent lamps are also almost absent from the market." GEF (2009) also states that "the prevalence of inefficient and outdated lighting technologies results in highly inefficient energy use patterns and vast energy saving potential. In public buildings alone, power demand for lighting is approximately $7 \mathrm{~W} / \mathrm{m}^{2} / 100 \mathrm{~lx}$, which is almost three times higher than the Organization for Economic Cooperation and Development (OECD) average of $2.5 \mathrm{~W} / \mathrm{m}^{2} / 1001 \mathrm{x}$. Overall, the generation of $1 \mathrm{Mlm}$ h of light flux in Russia requires $36 \mathrm{kWh}$, compared to 25-26 kWh in the European Union."

The Russian lighting industry has been in decline since the early 1990s. Despite some growth in 2003 to 2006, it has never fully recovered from the recession and economic restructuring. GEF reported that "In 2007, the national production volume was estimated at 639 million lamps, consisting primarily of incandescent lamps, linear fluorescent lamps (T12, T10 and T8) and high-pressure mercury lamps. In contrast, the import of lighting products has been steadily growing: in 2003 lighting imports were valued at \$30.8 million USD, in 2006 at \$87 million, and in 2008 at over $\$ 154$ million USD” (GEF 2009). By some analyses, the Russian lighting market is estimated to be worth around $\$ 1.92$ billion USD: with $\$ 1.32$ billion USD spent on lighting systems and fixtures, and $\$ 0.6$ billion USD on light sources (GEF 2009).

Although the share of energy efficient lighting products in the market remains negligible, the sector has significant growth potential. This is especially the case, since the Russian energy efficiency law introduced a ban on the sale of incandescent bulbs of 100 watts and higher in 2011 and broadened the gap to include all incandescent bulbs beginning in 2014. At the same 
time, GEF (2009) reports that "Domestic manufacturing is limited to two factories producing compact fluorescent bulbs: LISMA Lighting and Smolensk-Svet. While all modern technologies are available in principle, primarily through imports, there is virtually no domestic production of the most efficient technologies and overall supply is insufficient."

Perfecto Technology Co. Ltd (2012) reports that Chinese-made fluorescent and LED energy saving lighting products currently account for 60 percent of the LED market share in Russia. The biggest problem is poor quality; products do not meet the relevant technical standards and environmental requirements, the service life is low, and light products can cause harm to humans. Several European and U.S. manufacturers sell LEDs on the Russian market. There are also a few Russian suppliers. For example, Svetlana Optoelectronics has developed a variety of LED products. The company was founded in 1996 and is based in St. Petersburg. Its initial activities were focused on fire detection equipment, but most of its current business is for LED lighting. Svetlana Optoelectronics LED products include strips and modules for indoor lighting as well as exit signs, lit paving stones and underwater lights (Schaaf and Evans 2010).

\subsubsection{Insulation}

According to PMR reports (2010), most Russian buildings do not have proper insulation. Decades of cheap oil and natural gas have not encouraged construction developers and building managers to reduce their spending on heating. This led to buildings being poorly insulated and using energy extremely inefficiently (PMR 2010).

The following types of thermal insulation materials are used in Russia (along with some of the major manufacturers that supply the Russian market):

- mineral wool (made from basalt fibers) is commonly used for the thermal insulation of walls, facades and roofs, produced by the following companies: Paroc, Rockwool, Izovol, Isoroc, Izomin, Tekhno, Termosteps;

- glass wool: the main manufacturers include Saint-Gobain ISOVER, Ursa, Knauf Insulation, Termostek;

- expanded polystyrene (EPS) foam manufactured by Mosstroy-31, Primaplex, Penoplast, Styrofoam, Penoplex, Teplex;

- extruded polystyrene (XPS) - Ursa, Penoplex, Teplex, Tekhnoplex, KNAUF Therm, Penoplast (PRM 2010). 
Figure 2.2 Breakdown of the Russian Thermal Insulation Market in 2009 .

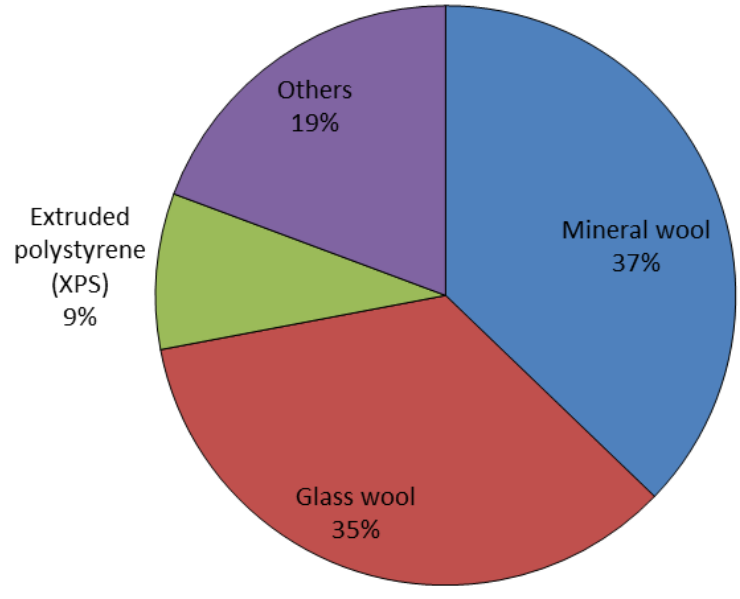

Source: Data adapted from PMR 2010.

Russian insulation material increased significantly between 2004 and 2008, when the market volume more than doubled. This was, however, followed by a reduction of more than 15 percent in 2009 (mimicking the drop in construction) and then stabilization in 2010 (PMR 2010).

Domestic manufacturing of insulation has increased rapidly, and the number of production facilities now exceeds 120 . The following insulation material is produced in the country:

- mineral wool (50 companies),

- glass wool (7 companies),

- extruded polystyrene (more than 16 companies) and

- expanded polystyrene (more than 50 companies) (PMR 2010).

The market is relatively concentrated, as the market share of the three main players combined makes up almost 50 percent. However, this structure has been shifting over the last few years (Fig. 2.3). For example, the share of URSA reduced from 25 percent in 2005 to about 17 percent by 2009. At the same time, Saint-Gobain ISOVER and Tekhno-Nikol increased their market shares. Today, the market shares held by the three main players are equal.

Figure 2.3 Major Insulation Producers in Russia in 2009.

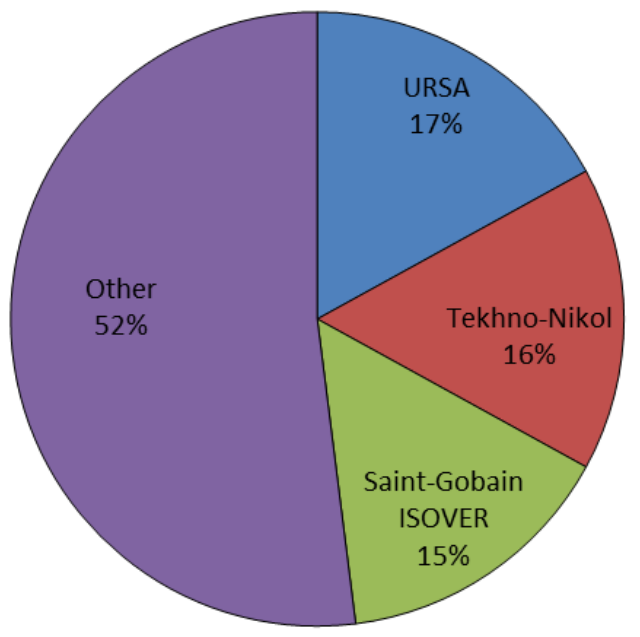

Source: Data adapted from PMR 2010. 


\subsubsection{Windows}

According to U.S. Commercial Service (2009), the Russian market for windows is divided into three segments: plastic, wooden and aluminum. As of September 2009, plastic (vinyl) framed windows accounted for 76 percent of the total market $\left(45.7\right.$ million $\mathrm{m}^{2}$ ), aluminum framed windows accounted for 13 percent $\left(7.5\right.$ million $\left.\mathrm{m}^{2}\right)$ and wooden framed windows accounted for 11 percent $\left(6.3\right.$ million $\left.\mathrm{m}^{2}\right)$. Since 2003 , the plastic (vinyl) framed windows segment has been growing an average of 30 percent per year and competition is stiff.

Double-glass pane windows have been increasingly popular, and their purchases significantly increased between 2005 and 2008. As incomes grew, Russians have been installing double-panes in new construction as well as older, Soviet-type buildings (Grishakova 2010).

In Moscow and its surrounding areas alone, there are about 3,500 plastic (vinyl) framed window manufacturers, although only a small fraction of these produce high-efficiency windows.

Numerous foreign manufacturers are active in the Russian market and some manufacture locally. Foreign competitors include German companies such as Rehau, KBE, Aluplast, Komerling, Geolan, Artec, Salamander, Veko, Tissen, Trocal; Austrian companies such as Shuko, Actual; Turkish companies such as Pak Pen, Pima Pen, Visesen, Winhaus, Windoline; Ukrainian companies such as Ekoplast, OpenTec, ALMplast; and Belgian companies such as Decuning and Kniping.

Figure 2.4 Russian Market Segmentation for Windows in 2009.

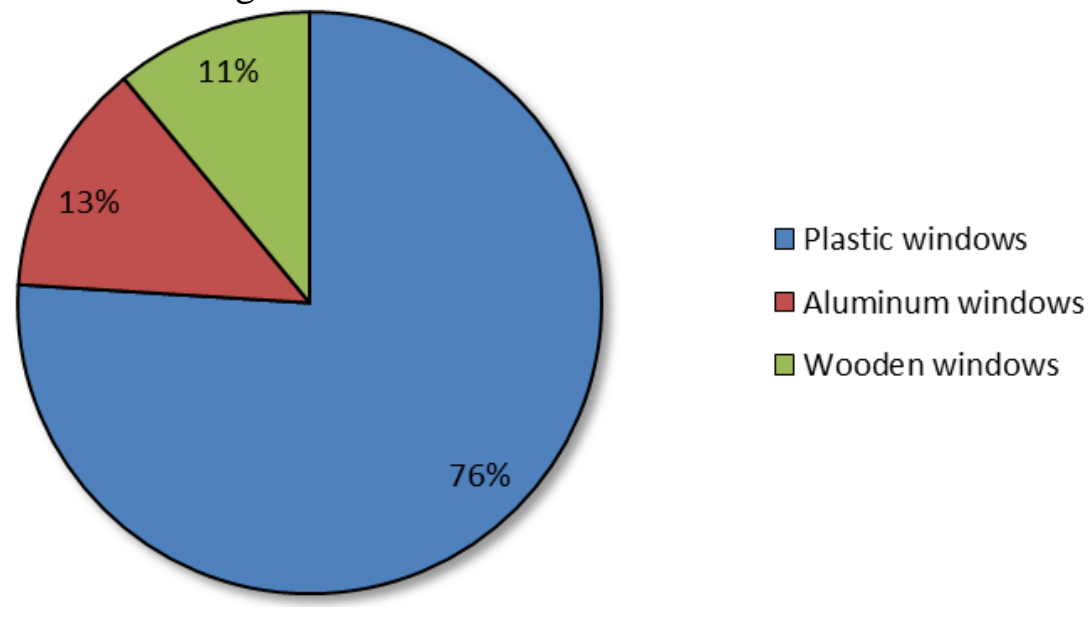

Source: Data adapted from U.S. Commercial Service 2009.

The Russian Energy Efficient Windows Manufacturers Association (APROK) has run a series of trade shows and events to promote efficient window sales in Russia (http://www.aprok.org/about_eng.php). The association also issues quality labels for certified windows. The labeling system is voluntary and based on random factory checks and selection by a committee. APROK has 150 industrial members, including Dow Corning and DuPont.

As the Russian building energy codes have strengthened in the past 15 years, the demand for more efficient windows and insulation has also grown. The current code (with different 
requirements by climate zone) is Construction Norm and Regulation 23-02-2003 (Ministry of Regional Development of Russian Federation 2002).

\subsection{Export and Technology Transfer Opportunities for the Building Sector in Russia}

Table 2.9 displays the U.S. Commercial Service's 2012 estimates for market size, local production exports, and imports of the Russian building/housing sector. Although market size and local production estimates reflect the economic downturn, total imports and U.S. imports grew steadily.

Table 2.9 Trade and the Housing Market in Russia, 2010-2013 (USD Thousands).

\begin{tabular}{|l|l|l|l|l|}
\hline Value of housing units & $\mathbf{2 0 1 0}$ & $\mathbf{2 0 1 1}$ & $\mathbf{2 0 1 2}$ (estimate) & $\mathbf{2 0 1 3}$ (estimate) \\
\hline Total market size & $14,700,000$ & $16,900,000$ & $15,300,000$ & $17,136,000$ \\
\hline Total local production & $8,500,000$ & $10,100,000$ & $9,300,000$ & $10,416,000$ \\
\hline Total exports & - & - & - & - \\
\hline Total imports & $6,200,000$ & $6,944,000$ & $7,777,280$ & $8,710,553$ \\
\hline Imports from the U.S. & 900,000 & $1,008,000$ & $1,128,960$ & $1,264,435$ \\
\hline
\end{tabular}

Source: Data adapted from U.S. Commercial Service 2012.

Russia presents many opportunities for U.S. environmental technologies companies to improve energy efficiency (U.S. Commercial Service 2012). As of 2012, energy efficiency and energy saving are the highest of the five priorities of the Committee on Modernization and Technological Development of the Economy under the aegis of the President of the Russian Federation created in 2009. The activity of the Committee aimed at complex implementation of six energy efficiency and energy saving projects:

- "Count, save and pay," focused on production, installation and use of metering as well as efficient energy consumption.

- "New lighting," focused on implementation of new lighting technologies and replacement of incandescent lamps with LED.

- "Energy efficient apartment blocks," focused on improving the efficiency of residential buildings.

- "Energy efficient social sector," emphasizing energy efficiency public buildings on the example of schools and hospitals.

- "Small complex power," dedicated to the use of small-scale local systems for heat and electricity production.

- "Innovative energy," focused on other innovative energy systems though national competitions (Committee on Modernization and Technological Development of the Economy under the aegis of the President of the Russian Federation 2012).

Prospective buyers of new environmental technologies include a wide range of construction firms, contractors and businesses that plan to renovate or construct local facilities. According to U.S. Commercial Service, "Non-Russian companies are more likely to use energy-efficient construction than Russian companies. Many foreign investors, especially European investors, 
will lend money for construction only if it meets certain environmental requirements, particularly sustainability and efficiency. European and American companies are also more likely to undertake green projects than Russian firms. For these reasons, non-Russian companies located in Russia offer opportunities to providers of energy-efficient and environmentally responsible building supplies and services" (U.S. Commercial Service 2012).

The most likely competitors for U.S. companies are European suppliers, who are very involved with green buildings and energy efficiency and view these as a form of corporate social responsibility.

Overall, opportunities in this market depend upon economic trends and national construction programs. As the Russian economy is growing, construction is also on the rise, along with major construction projects associated with the upcoming 2014 Olympic Games in Sochi and the 2018 FIFA World Cup. Another major green construction site is the Skolkovo Innovation Centre, a technology park outside of Moscow. Thus, Russian companies will continue to demand construction equipment and building materials. Given the reliability of foreign-manufactured equipment and building materials, Russian companies tend to prefer to purchase from Western manufacturers when quality is essential. However, price is also important, and Russian consumers are likely to opt for cheaper products. This implies that U.S. companies face strong competition with Chinese producers.

The growing demand for building materials and competition from cheaper Chinese products holds true in the residential market, too. Because 90 to 95 percent of Russian homes and apartments are sold without interior decorations, demand for these products is likely to continue growing. It should be noted that in Russia, the "Do It Yourself" approach is very popular, demonstrated by the success of stores like OBI, Castorama and IKEA, and therefore, retail purchases of building materials are likely to increase. Currently, about 20 percent of building materials is sold on the retail market to individual consumers (U.S. Commercial Service 2011).

Some of the key opportunities in Russian energy efficiency market for U.S. companies are summarized in the table below.

Table 2.10 Key Opportunities in the Russian Energy Efficiency Market.

\begin{tabular}{|l|l|}
\hline Opportunity & Description \\
\hline Moscow \\
expansion & $\begin{array}{l}\text { In 2011, then-President Dmitry Medvedev proposed to expand Moscow } \\
\text { boundaries and to create a new Federal District (RIA Novosti Aug. 2012). } \\
\text { According to the plan, in the next five years, Moscow will double in size, } \\
\text { annexing 144,000 hectares to the current territory. This is means that the } \\
\text { area is likely to add } 60 \text { million } \mathrm{m}^{2} \text { of housing and } 45 \text { million } \mathrm{m}^{2} \text { of } \\
\text { commercial real estate. The Moscow city government also recently held a } \\
\text { contest on the design on the new Federal District, which was won by a } \\
\text { British-American company Capital Cities Planning Group (Rosenfield } \\
\text { 2012). The development foresees a large share of green buildings and parks. }\end{array}$ \\
\hline Skolkovo & In 2010, the Russian Government announced plans to build the Silicon \\
\hline
\end{tabular}




\begin{tabular}{|l|l|}
\hline Innovation Center & $\begin{array}{l}\text { Valley of Russia - Skolkovo Innovation Center. The center is expected to } \\
\text { host 25,000-30,000 people on the territory of 380 hectares, and the } \\
\text { construction is planned to conform to international green construction } \\
\text { standards. This is a very innovative project for Russia, paving the way to } \\
\text { energy efficient building design and "green" waste-processing program } \\
\text { (UKTI 2012). The planned expense for Skolkovo is \$3.2-3.8 billion USD by } \\
\text { 2015 (UKTI 2012). }\end{array}$ \\
\hline Games in Sochi & $\begin{array}{l}\text { Russia's Sochi will host the XXII Olympic and XI Paralympic Winter } \\
\text { Games in February - March of 2014. As reported by U.K. Trade and } \\
\text { Investment (2010), about 218 projects will be constructed in Sochi. More } \\
\text { than \$35 billion USD will be spent on the preparation for the 2014 Winter } \\
\text { Olympic Games. Out of 202 planned Olympic builds, 10 will be LEED or } \\
\text { BREEM certified. Russia's Olympstoy will also certify 150 facilities as } \\
\text { energy efficient, although controversy remains over how green and efficient } \\
\text { the buildings will be once constructed. Most of the buildings still under } \\
\text { construction are in the hospitality sector (U.S. Commercial Service 2010). }\end{array}$ \\
\hline World Cup 2018 & $\begin{array}{l}\text { Another opportunity for businesses interested in entering Russian market is } \\
\text { FIFA World Cup 2018, which Russia will host. In addition to renovating } \\
\text { three existing stadium Russian Government plans to build 13 new stadiums } \\
\text { across the country, with a price tag of \$70 to \$300 million USD each. For } \\
\text { this purpose, the Russian Government plans to spend over \$9.4 billion USD. } \\
\text { The larger share of this funding will be spent after 2013 (UKTI 2012). }\end{array}$ \\
\hline
\end{tabular}

In addition to the opportunity above, the following industries offer promising opportunities for U.S. businesses:

\section{Hospitality}

The Russian hospitality market is expected to grow. The Moscow city government announced a plan to build 343 hotels with 92,700 rooms (Lenta.ru 2012). Demonstrating this trend, Marriot International is planning to build 20 hotels by 2015 (RIA Novosti Feb. 17 2012). In addition to Moscow, Mariott will put new hotels in Nizhny Novgorod, in the Republic of Tatarstan's Volga Region, Omsk in West Siberia, Kemerovo in East Siberia and Rostov in Russia's south. This can present excellent opportunities for U.S. companies interested in supplying energy efficient technologies to Russia.

\section{Retail}

Similarly, the Russian retail market is relatively unsaturated. According to U.K. Trade and Investment (2012), "In 2011 Russia remained in the top league of Central and Eastern European countries with the highest level of retail space development. Out of 146 shopping centers under construction in Europe in July 2011, Russia accounted for 19. Nearly one fifth of the first half of 2011's European development total, just over 400,000 m², was completed in Russia. Moscow 
accounted for 36 percent of that new space with the opening of AFIMALL City and two other shopping centers. Industry experts estimate that the Russian shopping centre pipeline for 2012 is about 3 million $\mathrm{m}^{2}$, of which 25 percent will be constructed in Moscow and the surrounding region." In addition, large cities outside the Moscow and St. Petersburg also present interesting opportunities, since the rents are reasonable and shopping center space is scarce.

\section{Residential}

Residential construction is also expected to grow, since the Russian Government announced plans to increase the volume of housing construction up to 90 million $\mathrm{m}^{2}$ annually by 2015 (UKTI 2012). Some of the projects present significant opportunities for U.S. exporters, since they are large-scale and emphasize the "green" aspect of construction:

- $\quad$ NCC (http://www.ncc-spb.ru/en) is building an apartment block area with a park, playgrounds, sport facilities, shops and parking in St. Petersburg. The project is expected to be completed by the end of 2014. "NCC is planning to use various new construction technologies, including energy efficient materials, to build a comfortable city living place that meets European standards" (U.S. Commercial Service 2012).

- BTK (www.btkdevelopment.ru) is developing a project that will build an energy efficient office building of 2,000 $\mathrm{m}^{2}$ in St. Petersburg. The building is planned in accordance with LEED standards and, when completed, the owners will apply for the certification.

- Setl City (http://www.setlcity.ru/en/) is starting to develop a project that will incorporate the following energy efficient technologies: a collector heating and water supply system, specially designed sanitation facilities and energy-efficient insulation and windows. The project is to be completed in the next 15-17 years.

Developing ESCO concepts in Russia represents another promising opportunity for U.S. companies to enter the Russian energy efficiency market. Since many facilities in Russia are old, outdated and inefficient, relying heavily on fossil fuels and non-automated boilers, control and air valve systems, potential energy savings are enormous even with minimal investment, presenting a healthy margin for ESCO profits. Since Russia is still a developing green energy market and ESCOs, while increasingly popular, remain uncommon, ESCO structures which offer short- and medium-term projects (six to ten years) are most likely to succeed (U.S. Commercial Service 2010).

Some of the factors that are expected to drive sustainable property development in Russia are listed below:

- The fact that certified green buildings have higher occupancy rates and faster turnover in Russia in general, which reduces developers' investment risks.

- Demand from international organizations and corporations for green offices due to international policies and standards (such as in the case of the Olympics of World Wildlife Fund's (WWF's) planned new headquarters in Moscow). 
- Government policies and initiatives to promote energy efficiency, including stronger implementation of building energy codes and requirements for substantial energy efficiency improvements in all government buildings. 


\section{Analysis of the Barriers to Doing Business and Improving Energy Efficiency in Russia's Building Sector}

\subsection{Barriers to Doing Business in Russia's Energy Efficiency Market}

Despite the fact that the energy efficiency market in Russia seems to be very large and receptive for the entrance of the U.S. companies, a number of barriers still exist which may slow down or make it difficult for interested U.S. businesses to enter Russian energy efficiency market.

Energy prices in Russia are low by international comparison. This is particularly true for heat and natural gas. This reduces the incentive to save energy.

There are also often split incentives for energy efficiency projects in buildings. For example, while most families own their own apartments, the building envelope, equipment and common spaces are managed by municipal companies that often have little incentive to invest in energy efficiency. In public buildings, the owner may invest in efficiency, but after a few years, the government budget for energy may then be reduced to reflect reduced cost, which reduces the owner's incentive in investing.

Financing can also be a challenge. In multi-family residential buildings, it is very difficult legally to pool funds for comprehensive retrofits. In public buildings, municipalities and other budget entities may have poor creditworthiness, which makes it difficult to seek loans or other financing.

Lack of knowledge and capacity on energy efficiency also affects the market. For example, there are relatively few qualified energy auditors who can in turn generate business for retrofits. Likewise, few banks, property developers and managers understand the benefits of efficiency and how they can use efficiency to boost profit and lower investment risk.

Many buildings have suffered from poor maintenance for decades. While on the one hand, this can present many opportunities for efficiency, capital renovation usually does not pay for itself with energy savings alone. Thus, some of the most cost-effective opportunities in buildings usually include lighting and controls. The harsh climate in Russia also typically makes most energy efficiency measures in buildings more cost-effective, particularly as one travels north.

Uneven implementation of commercial law creates further complications. Lack of transparency and a high regulatory burden are also major concerns, as documented by comparative surveys by Transparency International and the World Bank. On the other hand, after a 20-year process, Russia has just entered the World Trade Organization. This development will hopefully pave the way for increased competition on the Russian market, including competition from importers.

Another market challenge is Russia's vast territory, spanning nine time zones. Outside of the major cities, infrastructure, such as roads and transportation, is not very well developed, which can make accessing this vast country more challenging logistically. 


\section{Programs of Support Offered by the U.S. Trade Promotion Agencies}

The U.S. Government offers various programs, though a number of trade promotion agencies, to support U.S. businesses interested in entering new markets, such as Russia. Federal export assistance programs can be accessed through a centralized portal Exports.gov, managed by the International Trade Administration (ITA 2012a). The following agencies have offices and resources that assist U.S. exporters:

- International Trade Administration,

- U.S. Census Bureau, Department of Energy,

- Export-Import Bank,

- Foreign Agricultural Service (FAS),

- Agency for International Development (USAID),

- Overseas Private Investment Corporation (OPIC),

- Small Business Administration,

- Department of State,

- U.S. Trade and Development Agency (USTDA),

- Office of Foreign Assets Control and

- United States Trade Representative.

Some of the most relevant programs are summarized in Appendix B. 


\section{Conclusions}

Russia is one of the most energy intensive countries in the world with growing demand for energy. For this reason, Russia is a promising market for U.S. businesses interested in exporting energy efficient technologies, knowledge and services. Russia's economy is growing, as is the country's middle class, which demands improvements in energy efficiency and comfort levels of buildings.

Concurrently, there has been a legislative push to improve Russia's energy intensity. In 2008, Russian President Dmitry Medvedev identified energy efficiency as a top priority for modernizing the Russian economy and declared that energy efficiency and conservation are among the five strategic priorities for Russia's development. This has generated a demand in energy efficient products and services.

Currently, accumulated U.S. investment in Russia is approximately $\$ 10$ billion USD, and the U.S. is Russia's $10^{\text {th }}$ largest foreign investor (U.S. Commercial Service 2012). Based on the market analysis provided in this report, the Russian green building market is receptive for interested U.S. businesses wishing to export relevant technologies, products and experience to Russia. 


\section{Appendix A}

\section{Financing Mechanisms for Energy Efficiency Projects in Russia}

Appendix A provides more information on programs for financing energy efficiency in Russia construction sector, mentioned in Section 2.1.2.1. The information is taken directly from the agencies' websites.

\section{European Bank for Reconstruction and Development (EBRD)}

The text below is taken from the EBRD website at http://www.ebrd.com (EBRD 2010).

\section{General information}

The EBRD's multinational staff and in-house Board of Directors represent shareholders -63 countries and the European Union and European Investment Bank.

Programs/services available and requirements on qualifying for the assistance

EBRD's services aim to provide funds for well-structured, financially robust projects, engage in policy dialogue with governments and other international financial institutions (IFIs) and give targeted technical assistance. EBRD provides financing to businesses directly or through financial intermediaries, such as local banks and investment funds. The bank also provides support through business development programmes that help to promote new skills in the region.

The EBRD offers a wide range of financial instruments and takes a flexible approach in structuring its financial products.

\section{Direct financing}

The principal forms of direct financing provided by the EBRD are loans, equity and guarantees:

- loans are tailored to meet the particular requirements of a project. The credit risk may be taken entirely by the Bank or partly syndicated to the market.

- an equity investment may be undertaken in a variety of forms. When the EBRD takes an equity stake, it expects an appropriate return on its investment and will only take a minority position.

- guarantees are also provided by the Bank to help borrowers gain access to financing. 


\section{$\underline{\text { Assistance for small business }}$}

One of the EBRD's key aims is to support the development of micro, small and medium-sized enterprises (MSMEs) which are crucial to nurturing a private sector economy. To do this, we make equity and loan financing available to MSMEs through a range of intermediaries throughout our countries of operations.

These intermediaries include banks in which the EBRD has an equity stake or with which it has signed a loan, and investment or venture capital funds in which the EBRD has made an investment.

The EBRD also provides direct financing and support for MSMEs through a number of loan and equity facilities.

\section{$\underline{\text { Advice and guidance }}$}

The EBRD's complementary, donor-funded business development program - Enterprise Growing Program (EGP) and Business Advisory Services (BAS) - helps build stronger businesses.

EGP focuses on broad managerial and structural changes within small and medium-sized enterprises, bringing in sector-specific, internationally experienced executives from economically developed countries to help the businesses develop a new management culture and skills. BAS helps micro and small enterprises improve performance by supporting local consultants in projects with narrowly defined objectives and market development activities.

Both programs prepare enterprises for outside investment, including EBRD-financed projects.

\section{International Finance Corporation (IFC)}

The text below is quoted from the IFC website at http://www.ifc.org (IFC 2012).

\section{General information}

IFC's purpose is to create opportunity for people to escape poverty and improve their lives by:

- Mobilizing other sources of finance for private enterprise development

- Promoting open and competitive markets in developing countries

- Supporting companies and other private sector partners where there is a gap

- Helping generate productive jobs and deliver essential services to the poor and the vulnerable.

To achieve this purpose, IFC offers development-impact solutions through firm-level interventions (direct investments, advisory services, and the IFC Asset Management Company); 
by promoting global collective action; by strengthening governance and standard-setting; and through business-enabling-environment work.

Programs/services available and requirements on qualifying for the assistance

IFC provides advice, training and problem solving to companies, industries and governments. Because companies need a regulatory environment that enables entrepreneurship, IFC also work to advise national and local governments on how to improve their investment climate and strengthen basic infrastructure. Thus, governments make up around half of IFC's advisory portfolio.

We offer advice through nearly 1,100 Advisory Services staff in 85 offices across 73 countries. Funding comes from donor partners, IFC, and client contributions. In FY11, advisory services project expenditures totaled $\$ 206.7$ million. In all, 65 percent of project expenditures attributable to clients in individual countries went to IDA countries.

IFC financial products and investment services include:

- Loans

- Syndicated Loans

- Equity Finance

- Structured Finance

- Risk Management Products

- Local Currency Financing

- Trade Finance

$\underline{\text { Business lines }}$

- Access to Finance

- Investment Climate

- Sustainable Business

- Public-Private Partnerships

\section{Nordic Environment Finance Corporation (NEFCO)}

The text below is from the NEFCO website at http://www.nefco.org (NEFCO 2012).

\section{General information}

NEFCO is an international financial institution established by the five Nordic countries. NEFCO finances investments and projects primarily in Russia, Ukraine, Estonia, Latvia, Lithuania and Belarus, in order to generate positive environmental effects of interest to the Nordic region. 
With a capital of EUR 113.4 million, NEFCO operates as a partner, lender or guarantor in economically viable projects. The projects must, however, produce relevant environmental impacts in order to merit financing. The fund finances projects in Russia, Ukraine and Belarus as well as, for a limited period, in Estonia, Latvia and Lithuania. NEFCO gives priority to small and medium-sized projects that have positive environmental effects not only for the project country but also for the Nordic region, emphasizing mainly on projects that reduce harmful discharges into waterways and seas as well as reduce cross border airborne emissions.

The long-term participation of a Nordic partner is a prerequisite for the project to receive financing. This participation may include various forms of direct investment by a private or public enterprise. It can also be a project involving long-term deliveries. Nordic cooperation within the municipal sector, with the Investment Fund acting as financer, is also acceptable.

NEFCO requires that the projects financed by the Investment Fund should meet reasonable profitability criteria, but as long as this can be achieved, the primary focus is, however, on the positive environmental impacts. NEFCO always carefully examines the technical feasibility and financial profitability of all projects.

The Investment Fund provides capital investments or loans at market rates. Generally, the maximum investment loan per project is EUR 4-5 million. In capital investments, NEFCO's financing portion does not generally exceed 50 percent of the total investment. Regarding share capital, the financing portion is usually around 30 percent. 


\section{Appendix B}

Additional information on some of the U.S. Government agencies that assist U.S. companies in entering new markets, such as Russia

\section{Export-Import Bank of the United States ${ }^{6}$}

\section{General information}

The Export-Import Bank of the United States (Ex-Im Bank) is a federal government agency serving as the official export credit agency of the United States. Ex-Im Bank's mission is to help finance exports of U.S. goods and services to international markets.

Ex-Im Bank works with both large and small U.S. companies to facilitate export opportunities and create U.S. jobs.

Ex-Im Bank provides export financing products that fill gaps in trade financing. Specifically, ExIm Bank assumes credit and country risks that the private sector is unable or unwilling to accept. Ex-Im Bank also helps to level the playing field for U.S. exporters by matching the financing that other governments provide to their exporters.

Ex-Im Bank provides working capital guarantees (pre-export financing); export credit insurance; and loan guarantees and direct loans (buyer financing). On average, 85 percent of Ex-Im Bank transactions directly benefit U.S. small businesses.

Because of its export-related mission, Ex-Im Bank has strong requirements for U.S. content of any deal it finances.

\section{Programs/services available and requirements on qualifying for the assistance}

\section{$\underline{\text { Global Credit Express }}$}

The Global Credit Express program is specially designed to deliver short-term working capital loans directly to creditworthy small business exporters. Through this new program, exporters may be eligible for a 6- or 12-month revolving line of credit of up to $\$ 500,000$ USD. Global Credit Express adds liquidity to the U.S. small business export market by financing the business of exporting rather than specific export transactions. This is a pilot program currently offered through a select number of Originating Financial Institutions (lenders) nationwide.

\section{Express Insurance}

Express Insurance simplifies small business exporters' access to credit insurance on their shortterm export receivables. It also makes it easier for them to obtain financing of those receivables.

\footnotetext{
${ }^{6}$ The information in this section is taken from Export-Import Bank of the United States website (2012).
} 
A streamlined online application provides a policy quote and credit decisions up to $\$ 300,000$ USD on foreign buyers within five workdays or less (requests exceeding \$300,000 USD will require additional time).

\section{$\underline{\text { Renewable Express }}$}

Renewable Express helps U.S. exporters of solar-energy equipment, technology and services by providing streamlined financing of their exports to small solar-energy projects in international markets. Ex-Im Bank can consider project financing for small renewable-energy producers seeking loans of $\$ 3$ million to $\$ 10$ million USD in as few as 60 days.

\section{Supply Chain}

The Bank's supply-chain guarantee strengthens the supply chain by helping U.S. suppliers to expand their sales to U.S. customers that export. It increases liquidity for small-business suppliers by enabling participating lenders to purchase suppliers' accounts receivable that are due from U.S. exporters. It increases cash flow for small-business suppliers by ensuring the prompt payment of these receivables and lowering the cost of credit.

\section{$\underline{\text { Reinsurance }}$}

Ex-Im Bank's reinsurance ensures that U.S. small-business exporters can obtain private-sector insurance to cover the risks of nonpayment of foreign receivables. Participating private-sector insurers are eligible for reinsurance from Ex-Im Bank for short-term export-credit insurance policies supporting U.S. exports on repayment terms of 180 days or less (exceptionally up to 360 days). Ex-Im Bank's reinsurance mitigates the risks for private insurers and enables them to expand their underwriting capacity for these credits.

\section{Working Capital Guarantee}

\section{Pre-Export Financing To Help U.S. Exporters Maximize Borrowing Potential}

Ex-Im Bank's working capital financing enables U.S. exporters to obtain loans that facilitate the export of goods or services. These working capital loans, made by commercial lenders and backed by Ex-Im Bank guarantee, provide the liquidity to accept new business, grow international sales and compete more effectively in the international marketplace.

\section{Eligibility}

Eligible exporters:

- Must be located in the United States

- Must have at least a one-year operating history

- Must have a positive net worth 
Eligible exports:

- Must be shipped from the United States

- Products must have at least 50 percent U.S. content. (If less than 50 percent, then Ex-Im Bank can only support the export up to the percent of the U.S. content.)

- $\quad$ Services must be performed by U.S.-based personnel.

\section{Export Credit Insurance}

Ex-Im Bank's export credit insurance allows you to increase your export sales by limiting your international risk, offering credit to your international buyers, and enabling you to access working capital funds.

Ex-Im Bank's insurance covers the risk of buyer nonpayment for commercial risks (e.g., bankruptcy) and certain political risks (e.g., war or the inconvertibility of currency). This product can replace cash-in-advance, letters of credit, and other documentary sales. By limiting your risk, you can sell to more international buyers and compete vigorously in international markets.

Eligibility

Ex-Im Bank can do business in most markets. However, the Bank may be limited or unable to offer financing in certain countries and under certain circumstances. See Country Limitation Schedule.

Military or defense items are generally not eligible nor are sales to military buyers (with certain exceptions).

\section{$\underline{\text { Loan Guarantee \& Direct Loan }}$}

Ex-Im Bank assists exporters by guaranteeing term financing to creditworthy international buyers, both private and public sector, for purchases of U.S. goods and services. With Ex-Im Bank's loan guarantee, international buyers are able to obtain competitive term financing from lenders when financing is otherwise not available or there are no economically viable interest rates on terms over one-to-two years.

\section{Eligibility}

Ex-Im Bank's guarantee of a lender's loan to an international buyer is generally used for financing purchases of U.S. capital equipment and services.

Financing may also be available for:

- Refurbished equipment

- Software

- Certain banking and legal fees (See Financing Fees for Ancillary Services.)

- Certain local costs and expenses (See Ex-Im Bank Policies - Local Cost.) 
Military or defense items are generally not eligible nor are sales to military buyers (with certain exceptions).

\section{Finance Lease Guarantees}

Competitive Financing for International Buyers

Ex-Im Bank supports competitive medium-term financing structured as finance leases in addition to financing structured as installment loans. Support of lease financing is important since some foreign buyers of U.S. capital goods prefer lease financing as an alternative to traditional installment loans. Ex-Im Bank will guarantee lease financing of U.S. goods and services to creditworthy international lessees, both private and public sector, when financing is otherwise not available or applicable interest rates are not economically viable.

\section{$\underline{\text { Standardized Documentation }}$}

In order to provide accessible guarantee support for lease financing, Ex-Im Bank has created standardized guarantee documentation designed to meet the special requirements of this type of export finance. The MT Master Guarantee Agreement - Finance Lease provides equivalent ExIm Bank support for medium-term finance leases as is provided for traditional loan financing using Ex-Im Bank's MT Master Guarantee Agreement. Both Master Guarantee Agreements are compatible with the operational efficiencies of Ex-Im Bank's Medium-Term Electronic Compliance Program.

\section{$\underline{\text { Eligible Leases }}$}

Only finance leases ( as defined under International Accounting Standards) are eligible for ExIm Bank guarantee support. Under IAS 17, a lease is classified as a finance lease if it transfers substantially all the risks and benefits of ownership to the lessee. Full payout leases (i.e., those with no residual value) and transactions that are essentially "conditional sales" contracts often qualify as finance leases.

\section{$\underline{\text { Direct Loan }}$}

Fixed-Rate Term Financing for International Buyers

Ex-Im Bank assists exporters by providing fixed-rate loans to creditworthy international buyers, both private and public sector, for purchases of U.S. goods and services.

\section{Eligibility}

Ex-Im Bank's loan to an international buyer is generally used for financing purchases of U.S. capital equipment and services, and exports to large-scale projects. Financing may also be available for:

- Refurbished equipment 
- Software

- Certain banking and legal fees (See Financing Fees for Ancillary Services.)

- Certain local costs and expenses (See Ex-Im Bank Policies - Local Cost.)

\section{Environmental Export Financing:}

Ex-Im Bank's financing helps mitigate risk for U.S. environmental companies and also offers competitive financing terms to international buyers for the purchase of U.S.-made environmental goods and services.

Sectors:

Active portfolio that includes financing for U.S. exports of:

- Renewable energy equipment

- Energy efficiency technologies

- Wastewater treatment projects

- Air pollution technologies

- Waste management services

- Other various environmental goods and services

Ex-Im Bank support for U.S. environmental companies ultimately fuels U.S. job creation and the innovative research and development that allow the U.S. environmental industry to remain at the forefront worldwide.

Products:

Ex-Im Bank provides financing support through a wide range of products. These products include:

- Short-term working capital

- Export credit insurance

- Medium-term insurance

- Medium- to long-term loan guarantees

- Project and structured finance

- Long-term direct loans

These products allow Ex-Im Bank to act as an intermediary between exporters, lenders and buyers, helping to mitigate the risks associated with exporting to certain markets.

Enhanced Financing:

- Certain renewable energy and water transactions are eligible for 18-year repayment terms. 
- Environmental Exports Program enhanced financing makes international sales and projects more financially viable.

- All qualifying environmental export transactions, including renewable energy and water projects, are eligible for:

- Capitalized interest during construction.

- Automatic availability for up to 30 percent local cost financing.

\section{Contact information}

Export-Import Bank of the United States

811 Vermont Avenue, N.W.

Washington, DC 20571

Tel: (202) 565-3946 (EXIM) or (800) 565-3946 (EXIM)

http://www.exim.gov/

\section{Overseas Private Investment Corporation (OPIC) ${ }^{7}$}

\section{General information}

OPIC is the U.S. Government's development finance institution. It mobilizes private capital to help solve critical world challenges and in doing so, advances U.S. foreign policy. Because OPIC works with the U.S. private sector, it helps U.S. businesses gain footholds in emerging markets, catalyzing revenues, jobs and growth opportunities both at home and abroad. OPIC achieves its mission by providing investors with financing, guarantees, political risk insurance, and support for private equity investment funds.

Programs/services available and requirements on qualifying for the assistance

OPIC Financing provides medium- to long-term funding through direct loans and loan guaranties to eligible investment projects in developing countries and emerging markets. By complementing the private sector, OPIC can provide financing in countries where conventional financial institutions often are reluctant or unable to lend on such a basis.

OPIC's Small and Medium-Enterprise Financing is available for businesses with annual revenues of less than $\$ 400$ million USD. OPIC's Structured Financing focuses on larger U.S. businesses and supports large-scale projects that require large amounts of capital such as infrastructure, telecommunications, power, water, housing, airports, hotels, high-tech and financial services. OPIC can also provide long-term working capital and multiple-year capital expenditure programs. The amount of capital needed for any project can be greater than one financial institution can provide on its own due to per-project limits or diversifications guidelines. As a result, OPIC works with other co-lenders, if necessary, to bring sufficient resources to a project.

OPIC Financing offers a variety of loan structures to suit the unique needs of the projects it supports in developing nations.

\footnotetext{
${ }^{7}$ The information in this section is taken directly from Overseas Private Investment Corporation website (2012).
} 
- Corporate, Project, and Hybrid Loans

- Housing and Mortgage Financing

- Franchise Loan

- Commercial Bank On-Lending Agreements

In order to qualify for OPIC assistance:

1. The company should be a registered U.S. business

2. Proposed project should be in a country in which OPIC can do business

3. Proposed project should not fall within one of OPIC's categorically prohibited sectors

4. Proposed project should not result in the closing of a U.S. operation or a reduction of U.S. workforce

5. Proposed project should not fall within a sector that has experienced significant job loss in the U.S. within the past decade

6. Proposed project should uphold International Labor Organization worker rights standards

\section{Contact information}

1100 New York Avenue, NW

Washington, D.C. 20527

info@opic.gov

(202) 336-8400

www.opic.gov

\section{U.S. Commercial Service ${ }^{8}$}

\section{General information}

The U.S. Commercial Service is the trade promotion arm of the U.S. Department of Commerce's International Trade Administration. U.S. Commercial Service trade professionals in over 100 U.S. cities and in more than 75 countries help U.S. companies get started in exporting or increase sales to new global markets.

Programs/services available and requirements on qualifying for the assistance

\section{$\underline{\text { Trade Counseling }}$}

The U.S. Commercial Service helps potential exporters in various areas. Planning and Strategy

- Create a comprehensive international business plan for entry or expansion into targeted markets.

- Get ideas and cost-effective solutions to help achieve company's business goals.

\footnotetext{
${ }^{8}$ The information in this section is taken directly from ITA $2012 \mathrm{~b}$.
} 
Legal and Regulatory Issues

- Determine export licensing needs for shipping company's products.

- Understand and comply with global product standards, certification requirements, electricity regulations, and packaging laws.

- Learn how to avoid intellectual property rights issues and legal disputes.

Documentation and Product Requirements

- Learn about export documents, including Electronic Export Information filing, invoices, packing lists, and certificates of origin.

- Verify the tariff rate for company's product, as well as any import fees for a particular market.

- Determine your product's Schedule B and HS numbers.

Trade Problems

- Get assistance with customs-related issues.

- Obtain support from Commercial Service Advocacy Center if company's exports or foreign bids are adversely affected by a trade barrier or by market access issues.

- Learn how to limit the risk of non-payment, and receive counseling if problems arise.

Trade Finance and Insurance

- Formulate an export finance strategy leveraging loan programs provided by the ExportImport Bank of America, the Small Business Administration, and other trade finance organizations to reduce risk and enable company to offer competitive terms of sale.

- Get guidance on pricing company's products and services to ensure competitiveness in target markets while maximizing your profits.

Business Matchmaking

Contact Lists

- Identify potential partners.

- Research company market directly to local companies.

Partner Search

- Identify potential partners and get detailed company reports.

- Determine the marketability of product or service.

Personalized Business Matchmaking

- Meet one-on-one with pre-screened buyers, sales representatives, and business partners through U.S. Commercial Service Gold Key Service. 
- Leverage customized market briefings, research, and advice.

Trade Missions

- Participate in official business development missions led by senior U.S. Government leaders.

- Meet with agents, distributors, government and industry officials, prospective customers, and U.S. Embassy officials.

Trade Shows

In-Country Promotions

- Leverage customized venues to reach potential partners and buyers.

- Advertise in U.S. Commercial Service official catalog of U.S. suppliers sent to nearly 400,000 international companies.

- Feature your company on our local-language Web sites.

Market Intelligence

- Country and Industry Reports

- Customized Market Research

- Background Reports

- Trade Data and Analysis

- Commercial Diplomacy

Contact information

International Trade Administration

U.S. Department of Commerce

1401 Constitution Ave NW

Washington, DC 20230

www.trade.gov

\section{U.S. Trade and Development Agency ${ }^{9}$}

\section{General information}

USTDA is an independent U.S. Government foreign assistance agency that is funded by the U.S. Congress.

USTDA's mission is to help companies create U.S. jobs through the export of U.S. goods and services for priority development projects in emerging economies. USTDA links U.S. businesses

\footnotetext{
${ }^{9}$ The information in this section is taken directly from USTDA website (2012).
} 
to export opportunities by funding project planning activities, pilot projects, and reverse trade missions while creating sustainable infrastructure and economic growth in partner countries.

USTDA provides grant funding to overseas project sponsors for the planning of projects that support the development of modern infrastructure and an open trading system. The hallmark of USTDA development assistance has always involved building partnerships between U.S. companies and overseas project sponsors to bring proven private sector solutions to developmental challenges.

\section{Programs/services available and requirements on qualifying for the assistance}

International Business Partnership Program: Connecting U.S. Firms with Foreign Buyers

In support of the National Export Initiative, USTDA launched the International Business Partnership Program (IBPP) to connect international buyers with U.S. manufacturers and service providers in order to open new export markets and commercial opportunities around the world for American companies. Key activities include:

- Reverse Trade Missions

- Conferences and Workshops

- Training

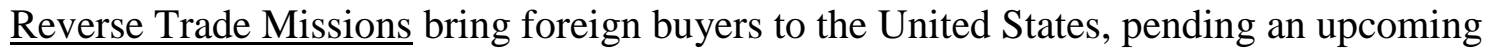
procurement, in order to observe the design, manufacture, demonstration and operation of U.S. products and services that can help them achieve their development goals. These strategically planned missions also present excellent opportunities for U.S. businesses to establish or enhance relationships with prospective overseas customers.

USTDA organizes worldwide conferences and workshops to connect U.S. firms with foreign project sponsors. These sector or region-specific events are designed to showcase U.S. goods, services and technology to foreign buyers. U.S. firms also have the opportunity to meet one-onone with overseas project sponsors. These events also provide U.S. companies with an understanding of U.S. government programs and the role they can play in supporting increased exports, from advocacy support to export financing options.

In support of U.S. businesses, USTDA provides training for foreign decision makers to support the sale of U.S. equipment and services overseas. Training can take place in either the United States or host country and it typically focuses on technology or regulatory requirements in order to give project sponsors a better understanding of U.S. capabilities and expertise related to a procurement opportunity.

\section{Project Development Program: Getting it right from the Start}

USTDA provides grants directly to overseas sponsors who, in turn, select U.S. companies to perform Agency-funded project development activities. An overseas sponsor is a local entity, public or private, with the decision-making authority and ability to implement a project. While 
USTDA projects span a variety of sectors, many focus on clean energy and energy efficiency, transportation, information and communications technology, and the environment. Key activities include:

- Feasibility studies

- Pilot projects

- Technical assistance

USTDA-funded and U.S.-led feasibility studies link foreign project sponsors with U.S. businesses at the critical early stage when technology options and project requirements are being defined. These studies provide the comprehensive analysis required for major infrastructure investments to achieve financing and implementation.

In some cases, export opportunities depend on a demonstration of the U.S. seller's goods, services or technologies in the foreign buyer's setting. USTDA-funded pilot projects demonstrate the effectiveness of commercially proven U.S. solutions and provide the analysis, evaluation and empirical data needed for potential foreign projects to secure funding.

USTDA advances economic development in partner countries by funding technical assistance that supports legal and regulatory reform related to commercial activities and infrastructure development, the establishment of industry standards, and other market-opening activities. These technical assistance programs facilitate favorable business and trade environments for U.S. goods and services.

\section{Contact information}

United States Trade and Development Agency 1000 Wilson Blvd., Suite 1600

Arlington, VA 22209

Phone: (703) 875-4357

Fax: (703) 875-4009

www.ustda.gov 


\section{References}

Administration of the City of St. Petersburg. 1999. "Opyt energosberezheniye v gorodskom khozyajstve Sankt-Petersburga [Experience in energy saving in the municipal sector of St. Petersburg]." Energosberezheniye. No. 3 (in Russian). Accessed online October 31, 2012 at: http://www.abok.ru/for_spec/articles.php?nid=166.

Alliance to Save Energy. 2007. "Guidelines for Financing Municipal Energy Efficiency Projects in the Commonwealth of Independent States." Accessed online October 31, 2012 at: http://www.munee.org/files/Financing_Guidelines_FINAL_Eng.pdf.

American Society of Heating, Refrigerating and Air-Conditioning Engineers (ASHRAE). 2012. "The Russian Standard on Green Building." Accessed online October 31, 2012 at: http://www.ashrae.org/resources--publications/periodicals/enewsletters/esociety/2012-03-14articles/russianstandard

Bashmakov, I. 2005. "Rossiyskiy opyt povysheniya energo-effektivnosti na obyektakh byudzhetnoy sfery [Russian experience in improving energy efficiency in the facilities of the budget sphere]." Chapter 3 in Povysheniye energo-effektivnosti v organizatsiyakh byudzhetniy sfery: vozmozhnosti dlya chastno-gosudarstvennogo partnerstva [Improving energy efficiency in the budget sphere: possibilities for public-private partnerships]. (In Russian). CENEf. Accessed online November 7, 2012 at: http://www.cenef.ru/file/FEMP-chap.3.pdf.

Caprio, C. 2012. "Improving Energy Efficiency in Russia: Real Progress and Present Challenges." Scholar Research Brief. IREX. Accessed online November 30, 2012 at: http://www.irex.org/sites/default/files/Caprio\%20EPS\%20Research\%20Brief_0.pdf.

Center for Energy Efficiency (CENEf). 2008. "Resource of energy efficiency in Russia: scale, costs and benefits." Accessed online October 31, 2012 at:

www.cenef.ru/file/Energy\%20balances-final.pdf.

Committee on Modernization and Technological Development of the Economy under the aegis of the President of the Russian Federation. 2012. Energoeffektivnost i resursosberezheniye [Energy Efficiency and Saving of Energy Resources] (in Russian). Accessed online November 6, 2012 at: http://www.i-russia.ru/energy/.

Continental Automated Buildings Association (CABA). 2007. Russian Market for Building Automation Systems. Available online at http://www.caba.org/resources/Documents/IS-200702.pdf.

Delyukin AS, Vasilyev AF and LYu Zhilina. 2002. "Opyt Sankt-Peterburga v realizatsii energosberegayushchikh proektov po rekonstruktsii sistemy teplosnabzheniya [St. Petersburg's 
experience in implementing energy saving projects based in upgrading heat supply systems]." Energosberezheniye. No. 3 (in Russian). Accessed online October 31, 2012 at: http://www.abok.ru/for_spec/articles.php?nid=1633.

ECE - United Nations Economic Commission for Europe. 2010. Potential and Best Alternatives for Investments in Implementing Interfuel Substitution in the Federal District of Siberia, Russian Federation. United Nations. Accessed online October 12, 2012 at: http://staging.unece.org/index.php?id=21782.

Ecological Systems. 2011. "V Irkutske budut stroit tolko energoeffektivnye doma [Only energy efficient homes will be built in Irkutsk]." ESCO. No. 12, December 2011 (in Russian). Accessed on October 29, 2012 at: http://journal.esco.co.ua/2011_12/art118.htm.

Ecological Systems. 2012. "Opisaniye proyektov po energosberezheniyu/ energoeffektivnosti v Rossiyskoy Federatsii [Description of energy saving/efficiency projects in Russian Federation]." ESCO. No. 4, April 2012 (in Russian). Accessed on October 29, 2012 at: http://journal.esco.co.ua/2012_4/art162.pdf.

Energosberezheniye. 2012. Report to PNNL titled "District heating in Chelyabinsk Region." College Park, MD.

Energy and Industry of Russia. March 16, 2012. "Tri doma Sankt-Peterburga poluchat besplatnye energosberegayushchiye svetilniki [Three buildings in St. Petersburg will receive free energy saving lighting." Accessed online October 31, 2012 at: http://www.eprussia.ru/news/base/2012/72120.htm.

European Bank for Reconstruction and Development (EBRD). 2010. "Our Services." Accessed online November 6, 2012 at: http://www.ebrd.com/pages/about/what/services.shtml (last updated April 6, 2010),

Evans M, V Roshchanka, S Parker and A Baranovskiy. 2012. Energy Efficiency Investments in Public Facilities Developing a Pilot Mechanism for Russia and Chelyabinsk Region. PNNL. Available at http://www.pnnl.gov/main/publications/external/technical_reports/PNNL21119.pdf.

Export-Import Bank of the United States. 2012. Accessed online November 6, 2012 at: http://www.exim.gov/.

Filatov, NV. 2009. "Moskva - pilotnyj region pri vnedrenii standardov marirovki energoeffektivnosti oborudovaniya [Moscow - pilot region for implementation of energy efficient equipment labeling]." Energosberezheniye. No. 1 (in Russian). Accessed online October 31, 2012 at: http://www.abok.ru/for_spec/articles.php?nid=4220. 
Global Environmental Facility (GEF). 2009. Russian Federation: Transforming the Market for Efficient Lighting. Project documentation. Accessed online October 15, 2012 at http://www.thegef.org/gef/sites/thegef.org/files/documents/document/Russia.Feb_.16.pdf).

GEF. 2010a. "GEF Project to Boost Urban Housing Energy Efficiency." Press release. Accessed online November 9, 2012 at:

http://www.thegef.org/gef/press_release/russia_energy_efficiency_2010.

GEF. 2010b. Improving Efficiency in Public Buildings in the Russian Federation - under the Energy Efficiency Umbrella Program. Project documentation. Accessed online November 9, 2012 at: http://www.thegef.org/gef/sites/thegef.org/files/documents/document/10-062010\%20ID3596\%20\%20-\%20\%20\%20Council\%20Letter.pdf.

Government of the Russian Federation. 2010a. State Program of the Russian Federation "Energy Savings and Increasing Energy Efficiency to 2020." Confirmed by Order of the Russian Government, December 27, 2010, No. 2446-r. Available at: http://rosenergo.gov.ru/info/docs/. Government of the Russian Federation. 2010b. Federal Law on Heat Supply. (As amended in 2011, available through: www.consultant.ru).

Grishakova, E. 2010. Market research of window units and doors industry in Russia. Bachelor's thesis. Haaga-Helia University of Applied Sciences. Accessed online November 6, 2012 at: https://publications.theseus.fi/bitstream/handle/10024/15216/Market_research_windows_doors Russia.pdf?sequence $=1$.

International Energy Agency (IEA). 2004. Coming in from the Cold: Improving District Heating Policy in Transition Economies. OECD Publishing, Paris.

IEA. 2010. World Energy Statistics 2010. CD-ROM. OECD Publishing, Paris

IEA. 2011. World Energy Outlook 2011. OECD Publishing, Paris.

International Finance Corporation (IFC). 2012. IFC's Vision, Values and Purpose. Accessed online November 9, 2012 at:

http://www1.ifc.org/wps/wcm/connect/corp_ext_content/ifc_external_corporate_site/about+ifc/v ision/about_ifc_vision.

IFC and EBRD. 2012. Financing Capital Repairs and Energy Efficiency Improvements in Russian Multi-family Apartment Buildings. Accessed online October 31, 2012 at:

http://www.ebrd.com/downloads/sector/sei/capital-repairs.pdf.

IFC and World Bank. 2008. Energy Efficiency in Russia: Untapped Reserves. 46936. The World Bank in cooperation with International Finance Corporation, Washington, D.C. Accessed online October 31, 2012 at: http://documents.worldbank.org/curated/en/2008/12/10123872/ energy-efficiency-russia-untapped-reserves. 
International Trade Administration (ITA). 2012a. Export.gov's Partner Agencies. Export.gov. Accessed online November 12, 2012 at: http://export.gov/about/eg_main_016802.asp.

ITA. 2012b. Services for U.S. Agencies. Accessed online November 12, 2012 at: http://www.trade.gov/cs/services.asp.

ISOVER. 2012. Proekty 'multikomfortnykh domov ISOVER' [Projects 'multi-comfort buildings ISOVER']. Accessed online October 31, 2012 at: http://www.isover.ru/index.php?pid=66.

Kanev, SN. 2011. "Energoeffektivnyj dom v Khabarovske [Energy efficient home in Khabarovsk]." Energosberezheniye. No. 5 (in Russian). Accessed online October 31, 2012 at: http://www.abok.ru/for_spec/articles.php?nid=4987.

Khromkin, VA. 2000. "Opyt energosberezheniya v osvetitelnykh ustanovkakh moskovskogo metropolitena [Energy saving experience in lighting fixtures of Moscow metro system]." Energosberezheniye. No. 6 (in Russian). Accessed online October 31, 2012 at: http://www.abok.ru/for_spec/articles.php?nid=152.

Konstantinov, VA. 2012. "Povysheniye energoeffektivnosti obshchestvennogo zdaniya v Moskve [Improving energy efficiency in public buildings in Moscow]." Energosberezheniye. No. 3 (in Russian). Accessed online October 31, 2012 at: http://www.abok.ru/for_spec/articles.php?nid=5236.

Korppo A and N Korobova. 2012. "Modernizing residential heating in Russia: End-use practices, legal developments and future prospects." Energy Policy, 42:213-220.

Kotov SI, Nikitin VM and VA Stennikov. 2001. "Opyt realizatsii proyekta 'rekonstruktsiya sistemy teplosnabzheniya Novo-Lenino g. Irkutska na osnove energosberegayushcikh tekhnologiy [Experience in implementing project 'reconstruction of heat supply system of NovoLenino district of the town of Irkutsk on the basis of energy saving technologies']." Energosberezheniye. No. 2 (in Russian). Accessed online October 31, 2012 at: http://www.abok.ru/for_spec/articles.php?nid=149.

Lenta.ru. June 14, 2012. "Do 2025 goda v Moskve postroyat 340 novykh gostinits [By 2025, 340 new hotels will be built in Moscow]." (In Russian). Accessed November 6, 2012 at: http://realty.lenta.ru/news/2012/06/14/hotels/.

Ligun, LE. 2005. “Avtomatizirovanaya sistema dispetcherskogo upravleniya zhilym kompleksom na primere ZhK 'Vorontsovo' g. Moskvy [Automated dispatch system for residential complexes on the example of 'Vorontsovo' complex in Moscow]." Energosberezheniye. No. 3 (in Russian). Accessed online October 31, 2012 at: http://www.abok.ru/for_spec/articles.php?nid=2875. 
Litvinchuk's Marketing Agency. 2001. Russian market is expected to grow owing to sales in regions. Available online at http://www.litvinchuk.ru/en/articles/folder/8.html.

Maksimenko VA and RV Vroblevskiy. 2005. "Mirovye tendentsii i perspektivy razvitiya stroitelstva intellektualnykh zdaniy v Rossii [Global trends and opportunities for intelligent building construction in Russia]." Energosberezheniye. No. 6 (in Russian). Accessed online October 31, 2012 at: http://www.abok.ru/for_spec/articles.php?nid=2971.

Mazneva, E. 2012. "Energy Efficiency Struggles against a the Paradox of Abundance." The Moscow Times. Accessed October 30, 2012 at:

http://www.themoscowtimes.com/special/environment/eng/energy-efficiency-struggles-againstthe-paradox-of-abundance.html\#ixzz252mywluv.

McKinsey \& Company. 2009. "Pathways to an Energy and Carbon Efficient Russia." Available online at: http://www.mckinsey.com.

Ministry of Energy of the Russian Federation. 2010. Energy Strategy of Russia for the Period of up to 2030. Approved by Decree No. 1715r of the Government of the Russian Federation dated November 13, 2009.

Ministry of Regional Development of the Russian Federation. 2002. Construction Norms and Regulations. Thermal Performance of Buildings. SNiP 23-02-2003. Approved by the Federal Law No. 184-FZ dated December 27, 2002. Accessed online November 1, 2012:

http://www.rosteplo.ru/Npb_files/npb_shablon.php?id=306.

Nekrasov A, Y Sinyak, S Voronina, and V Semikashev. 2011. "State-of-the-art of Russia's heat supply systems.” Studies on Russian Economic Development, 22(1):20-30.

Nordic Environment Finance Corporation. 2012. NEFCO. Accessed online November 9, 2012 at: http://www.nefco.org/.

Obetkon, R. 2011. “Construction industry in Russia sees long-awaited upsurge.” In Construction sector in Russia H2 2011 - Development forecasts for 2011 - 2014. PMR Publications. Summary available at http://stroyexpo.sibfair.ru/eng/?current=3579\&nid=350.

Obetkon, R. 2012. "Construction industry in Russia continues to grow." In Construction sector in Russia H1 2012 - Development forecasts for 2012 - 2014. PMR Publications. Summary available at http://www.constructionrussia.com/167060/Construction-industry-in-Russiacontinues-to-grow.shtml.

Overseas Private Investment Corporation. 2012. Accessed online November 6, 2012: www.opic.gov/.

Pacific Northwest National Laboratory. 2012. "Investments into Energy Efficient Renovations of Residential Multi-family Buildings in Russia.” In International Building Energy Exchange 
(IBEX) database. Accessed November 9, 2012 at:

http://ibex.pnnl.gov/wiki/index.php/Investments_into_Energy_Efficient_Renovations_of_Reside ntial_Multi-family_Buildings_in_Russia.

Perfecto Technology Co. Ltd. 2012. Available online at http://blog.perfectoled.com/russiasenergy-efficient-lighting-products-market/

RIA Novosti. February 17, 2012. "Marriott Plans to Open 20 Russian Hotels by 2015." Accessed online November 6, 2012 at: http://en.rian.ru/business/20120217/171360655.html.

RIA Novosti. February 21, 2012. "Pervyj v RF poselok polnostyu na svetodiodakh poyavilsja v lenoblasti [The first in Russian Federation settlement fully on LED appeared in Leningrad Region]." Accessed online October 31, 2012 at: http://ria.ru/technology/20120221/571467916.html.

RIA Novosti. August 14, 2012. "Putin Demands Strict Control over 'New Moscow' Funds". Accessed online, November 6, 2012 at: http://en.rian.ru/trend/Moscow_expansion/.

PMR. 2010. "The changing structure of the thermal insulation material in Russia." Accessed online October 31, 2012 at: http://www.pmrpublications.com/free_stuff/880/the-changingstructure-of-the-thermal-insulation-material-market-in-russia-december-2010.

PMR. 2012. "Russian construction data." Accessed on October 31, 2012 at: http://www.constructionrussia.com/Russian_Construction_Data.shtml.

Rosenfield, K. September 13, 2012. "Winning Team Announced for Moscow Expansion" ArchDaily. Accessed 07 Nov 2012 at: http://www.archdaily.com/273322.

Russian Statistical Agency (Rosstat). 2011. Statistical Yearbook 2011, Construction Chapter, available at: www.gks.ru/wps/wcm/connect/rosstat/rosstatsite/main/publishing/catalog/ statisticCollections/doc_1135087342078.

Russian Sustainable Architecture and Building Council (RSABC). 2012. "Sertifikatsiya [Certification]" (in Russian). Accessed online November 2, 2012 at:

http://rsabc.ru/ru/pages/4.htm.

Sberbank. 2012. "Na puti k ekologicheskoy effektivnosti [On the way towards environmental effectiveness]." (In Russian). Accessed online November 30, 2012 at http://www.sbrf.ru/moscow/ru/about/philanthropy/society/303025/.

Schaaf R and M Evans. 2010. Russia's R\&D for Low-Energy Buildings: Insights for Cooperation with Russia. PNNL-19488. Pacific Northwest National Laboratory, Richland, WA. Available at http://www.pnnl.gov/main/publications/external/technical_reports/PNNL19488.pdf. 
Zissis G, Aizenberg J and A Shevchenko. 2010. Transforming the market for efficient lighting, Russia. Light and Engineering. 18 (1): 12-19. Znack Publishing House, Moscow.

Skripitsyn AS and AA Shmaenik. 2003. "Maloetazhnyi zhiloy kvartal g. Petrozavodska s uluchshennymi arkhitekturno-planirovochnymi, konstruktivnymi i inzhenernymi resheniyami zdaniy [Low-rise residential block of the town of Petrozavodsk with improved architecture, construction and engineering solutions for buildings]." Energosberezheniye. No. 1 (in Russian). Accessed online October 31, 2012 at: http://www.abok.ru/for_spec/articles.php?nid=1977.

U.K. Trade and Investment (UKTI). 2010. “Olympic opportunities in Russia.” Accessed online October 31, 2012 at: http://ukti.gov.uk/export/countries/asiapacific/southasia/india/sectorbriefing/111046.html.

UKTI. 2012. "Construction Industry in Russia.” Accessed online October 31, 2012 at: http://www.ukti.gov.uk/export/countries/sectorbriefing/268980.html.

United Nations Framework Convention on Climate Change - Joint Implementation. 2012. RU1000318: The implementation of energy efficiency measures at Chelyabinsk Electrometallurgical Works, OJSC. Accessed on October 31, 2012 at: http://ji.unfccc.int/JIITLProject/DB/8YUBL66VI1AHLSPZQ7VFESMFEASV3P/details (last updated April 3, 2012).

U.S. Commercial Service. 2009. Russia: Building Products Industry. Accessed on October 31, 2012 at: http://www.ado.alabama.gov/content/media/publications/trade/mission/russia/RUS 20Building\%20Products\%20Industry\%20110209.PDF.

U.S. Commercial Service. 2010. Russian Federation: Green Building and Construction Market Research Report. Accessed online October 31, 2012 at: http://www.buyusainfo.net/z_body.cfm?dbf=ccg1\%2Cbmr11\%2Cmrsearch1\&search_type2=int $\underline{\text { \&avar }=19999 \& \text { sector }=1009 \& \text { region }=\text { Eastern } \% 20 \text { Europe } \& \text { country }=\text { Russia } \& \text { logic }=\text { and } \& \text { loadnav }}$ =no.

U.S. Commercial Service. 2011. Doing Business in Russia: 2011 Country Commercial Guide for U.S. Companies. Accessed on October 31, 2012 at: https://www.webportglobal.com/CMSPages/GetFile.aspx?guid=9d114adb-505f-4cde-93e2eaca9eb7236a.

U.S. Commercial Service. 2012. Doing Business in Russia: 2012 Country Commercial Guide for U.S. Companies. Accessed on October 31, 2012 at: http://www.buyusainfo.net/docs/x_2871072.pdf.

U.S. Trade and Development Agency. 2012. U.S. Trade and Development Agency. Accessed online November 12, 2012 at: http://www.ustda.gov/. 
Vasiliev GP and NS Krundyshev. 2002. "Energoeffektivnaya selskaya shkola v Yaroslavskoy oblasti [Energy-efficient rural school in Yaroslav Region]." ABOK. No. 5 (in Russian). Accessed online October 31, 2012 at: http://www.abok.ru/for_spec/articles.php?nid=1659.

\section{Pacific Northwest}

NATIONAL LABORATORY

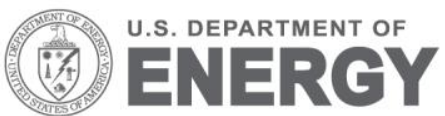

Proudly Operated by Battelle Since 1965

902 Battelle Boulevard

P.O. Box 999

Richland, WA 99352

1-888-375-PNNL (7665)

www.pnnl.gov 